\title{
The Role of Venture Capital in the Entrepreneurial Finance Ecosystem: Future Threats and Opportunities
}

\author{
Stefano Bonini \\ Stevens Institute of Technology \\ School of Business \\ 1 Castle Point on Hudson, Hoboken, 07030 NJ, USA \\ Vincenzo Capizzi ${ }^{1}$ \\ Department of Economics and Business Studies \\ Università del Piemonte Orientale \\ Via E. Perrone, 18, 28100, Novara, Italy
}

${ }^{1}$ Corresponding Author. Tel.: +39 0321 375.438. Email: vincenzo.capizzi@uniupo.it

We are deeply indebted with Josh Lerner for the inspiring keynote lecture given at the Conference "Emerging Trends in Entrepreneurial Finance", at Stevens Institute of Technology (Hoboken, NJ, US) in May 2017. Josh Lerner also read the current draft and offered insightful suggestions. We thank Università del Piemonte Orientale and Stevens Institute of Technology for financial support. We are grateful for the helpful comments from Tiago Botelho, Douglas Cumming, Richard Harrison, Colin Mason, Peter Wirtz. Any errors are our responsibility. 


\begin{abstract}
Despite the enduring relevance of venture capital as a source of funding for new firms, the last decade has seen the emergence of multiple alternative sources of funding, radically reshaping the start-up eco-system and posing new questions for both academics and practitioners. In this review paper, we provide a comprehensive analysis of the challenges and opportunities opened by these new financing structures, trying to shed light on the features, investment policies and risk-return profiles of institutional and informal investors providing capital to early stage companies.

We begin by critically reviewing the strengths and weaknesses of the main alternative capital providers. We then highlight that traditional closed-end venture capital funds, while experiencing competitive pressure, still play a critical role in the financing structure of new firms because of their unique production process and distinctive competences. With conclude by providing a comprehensive representation of the complex and multidimensional nature of startups that can be useful to identify more effective fundraising strategies and tackle new and yet unexplored research questions.
\end{abstract}




\section{Introduction: is venture capital close to its demise?}

In the recent past, one common approach used to identify the funding options available to corporate entities has been based upon the positioning of the company in its lifecycle, which allows the decomposition of the capital market industry in different segments, each one of them well suited for relatively homogeneous batches of companies in terms of maturity, stage of development, size, typical investment needs, information availability, corporate ownership and governance models (Ang, 1992; Carey et al. 1993; Petersen and Carpenter, 2002).

For interpreting the concrete behavior of corporate managers when designing the capital structure of the company they are running, finance theory has developed different alternative explanations, such as the trade-off theory (Modigliani and Miller, 1958; 1963; De Angelo and Masulis, 1980; Fama and French, 2002)), the agency theory (Jensen and Meckling, 1976; Myers, 1977; Jensen, 1986) and the pecking order theory (Myers and Majluf, 1984). However, when focusing on young SMEs, it is widely accepted that information asymmetries together with firm size and age play a major role in determining both what segment of the capital market - public or private - and what financing facilities to seek access to at each stage of a company's life cycle, as illustrated in Fig. 1 (Berger and Udell, 1998).

Furthermore, at various points in a company's growth path, such an approach allows the identification of potential funding gaps that could be filled through appropriate funding strategies aimed at finding the most suitable type of financial investor (Mason, 2006; Sohl, 2007). Focusing in particular on young or newly created small and medium sized-enterprises (SMEs), empirical evidence shows each financial system is affected by a certain amount of allocative inefficiency, concretely resulting in a gap - often referred to as the "primary funding gap"- - between the demand for financial resources by startup companies and the supply of early-stage equity capital (Mason and Harrison, 2000, Hall and Lerner, 2010; Landström and Mason, 2016, Wilson et al., 2018).

According to the standard pecking order theory, for sources of finance, after the choice of internal financing represented by the "insider seed money" coming from entrepreneurs and eventually from the "family and friends tranche", the domain of venture capital, for a long time commonly identified as the unique source of external finance available to startups, due to the uniqueness of their operations and investment practices, begins. ${ }^{2}$ Due to their expertise in certain areas, such as the screening process (Chan, 1983; Wright and Robbie, 1998; Cumming, 2006; Chemmanur et al., 2011), the monitoring of

\footnotetext{
${ }^{2}$ Internal finance could possibly be complemented by entrepreneurial bootstrapping (Winborg and Landstrom, 2001) and trade credit, which is more likely than short-term bank debt to be offered to startups and credit-constrained SMEs (Petersen and Rajan, 1997). However, due to the high mismatch between the maturities of assets and liabilities, both

such sources of financing are not to be used in order to meet the fixed asset investment needs companies typically have to face in their start-up phase, ,ultimately further increasing business risk.
} 
contractual provisions (Admati and Pfleiderer, 1994; Gompers, 1995; Bergemann and Hege, 1998; Kaplan and Stromberg, 2003; Cumming and Johan, 2013), the staged investing mechanism (Sahlman, 1990; Bergemann and Hege, 1998; Cornelli and Yosha, 2003) implementation, the syndication of investments (Lerner, 1994; Filatotchev et al., 2006; Manigart et al., 2006; Tian, 2011), and exit practices (Black and Gilson, 1998; Hellmann, 2006, Giot and Schwienbacher, 2007), as well as due to the compensation schemes applied to the executives of venture capital closed-end funds or to the general partners of venture partnerships (Gompers and Lerner, 1999; Metrick and Yasuda, 2010), venture capital firms, since their origins in the aftermath of the end of World War II, have been the actors of the early-stage financing industry, intercepting and investing the highest volumes of capital resources (Bruton et al., 2005; Kaplan and Lerner, 2017). ${ }^{3}$

Figure 1 - Firm continuum and sources of finance

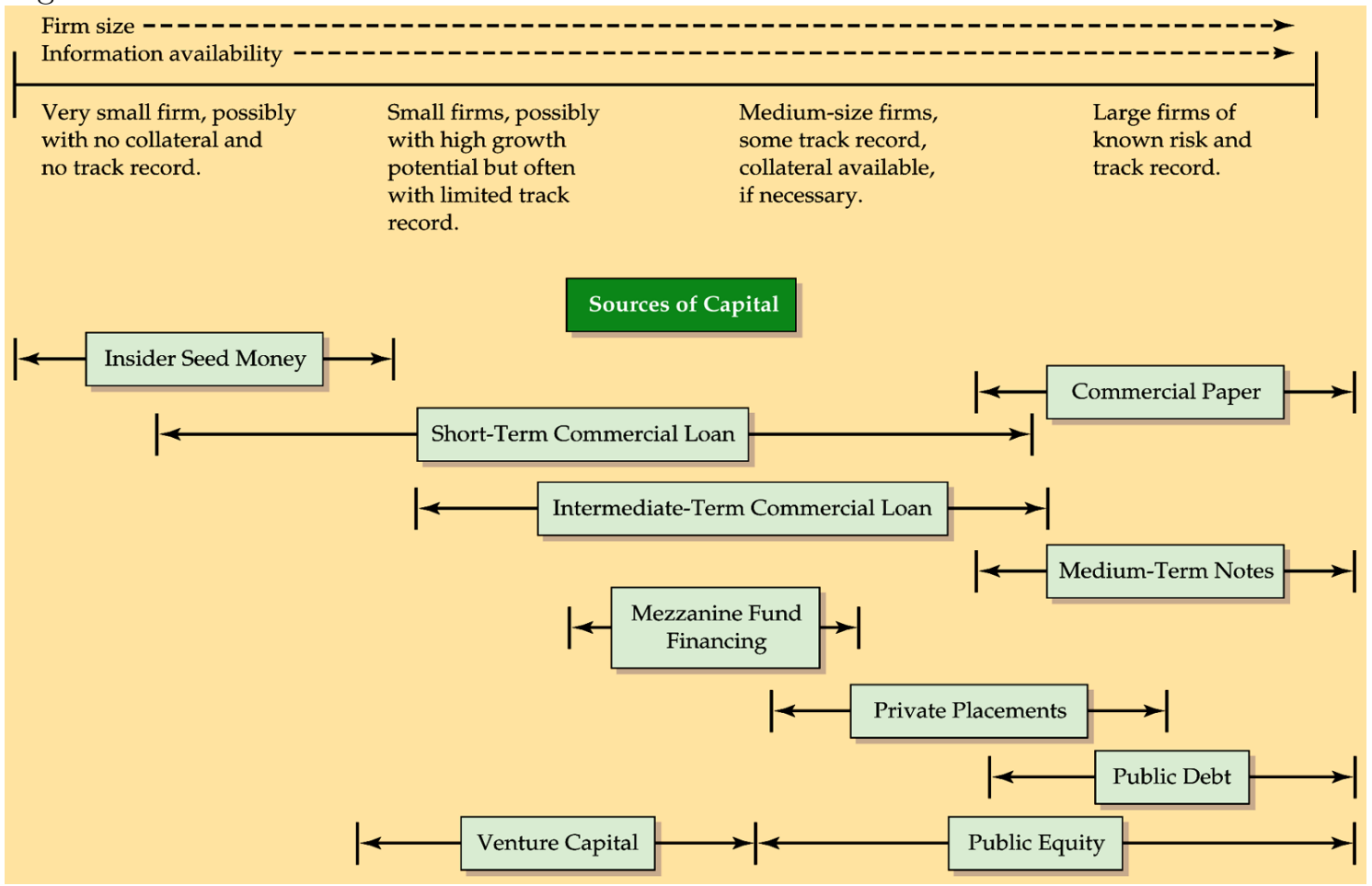

Source: Berger and Udell (1998)

Thus, in the standard representation of the business financing cycle, for the startup company, the capability to raise equity capital from a venture capitalist or a syndicate of venture capitalists does also constitute a crucial and visible achievement, representing a capability that may be brought from its preliminary stages for use in

\footnotetext{
${ }^{3}$ See the annual statistics about venture capital and private equity investments collected and processed by NAVCA

for the US, Invest Europe (formerly, EVCA) for Europe, and by AVCJ for Asia.
} 
later ones where bank lending-based indirect finance, on the one hand, and direct finance (IPOs and bond issues), on the other hand, are the most accessible and convenient financing facilities available. Indeed, within the venture capital industry, in order to complete such a growth path, it was a common case to pass through multiple follow-on investments involving either the existing venture capitalists or a new set of investors, giving rise to series $\mathrm{A}, \mathrm{B}, \mathrm{C}$ and $n$ funding rounds.

However, despite the continuing relevance of the venture capital industry, over the last decade, we have been observing the growing emergence of alternative sources of funding within the early-stage financing industry, ultimately radically changing and reshaping the start-up eco-system, as well as the entrepreneurial finance literature (Bruton et al., 2015; Fraser et al., 2015; Landström and Mason, 2016; OECD, 2017; Bellavitis et al., 2017). These alternative sources of funding involve many heterogeneous players, such as incubators, accelerators, science and technology parks, university-affiliated seed funds, corporate seed funds, business angels-including "super-angels", angel groups, business angel networks and angel investment funds - and both equity- and debt-based crowdfunding platforms (Mitchell, 2010; Hoffman and Radojevich-Kelley, 2012; Capizzi and Carluccio, 2016). Each one of these investors has peculiar risk-return profiles and investment philosophies, their own investment practices and preferred exit options, making it a major challenge for scholars as well as for practitioners and policymakers to identify the kind of relationships possibly existing among each other in order to design a linear and well-structured startup financing path involving all of them (Hellmann et al. 2017).

The startup ecosystem is then completed by nonequity financing investors - such as banks, government and regional development agencies - and by other actors providing contributions to either entrepreneurs or investors or both, such as advisors, lawyers, investment banks, gatekeepers, foundations and nonprofit organizations, governments, universities and research centers, and other service providers (Busenitz et al., 2003; Isenberg, 2010; OECD, 2011, Wilson, 2015).

On the opposite side, the rise of new actors supporting the development of startups and young SMEs is not the only phenomenon affecting the venture capital industry: large financial institutions experienced in operating in the capital markets, investing in latestage and mature companies, increasingly began diversifying their investment portfolios and as a consequence, have tried to "get in the venture game" through, in some cases, the well consolidated business model of closed-end funds, based on the separation of the asset managers (the "general partners") and the investors (the "limited partners"), and in other cases, through direct investments by the limited partners or through coinvestments alongside the closed-end funds. Among the actors today increasingly assuming equity positions in startups - the so-called "alternative investments" asset class - there are large private equity and buyout funds - either publicly traded or unlisted-hedge funds, funds of funds, sovereign wealth funds, foundations and endowments, private debt, mezzanine funds, holding companies listed special purpose acquisition vehicles, insurance companies and pension funds (Chernenko et al., 2017). 
In recent years, a prominent example of the dramatic change transforming the earlystage financing industry is UBER, who-according to Crunchbase data-passed through 15 funding rounds in not even 7 years (from Aug 1, 2009 to July 7, 2016), raising more than $\$ 12$ billion and involving, after the founders' investment, an angel round, 8 follow-on venture rounds, 3 private equity rounds and two debt financing rounds (Fig. 2).

Figure 2 - Uber funding rounds in the 2009 - 2016 period

\begin{tabular}{|c|c|c|c|}
\hline \$200K / Seed Aug 1, 2009 & $\$ 37$ M / Series B Dec 7, 2011 & \$1.2 B / Series E Dec 4, 2014 & \$200M / Private Equity Feb 12, 2016 \\
\hline Garrett Camp & Menlo Ventures (Lead) & Lone Pine Capital & LetterOne \\
\hline \multirow[t]{2}{*}{ Travis Kalanick } & Benchmark & New Enterprise Associates & \\
\hline & Bobby Yazdani & Qatar Investment Authority & \$3.5 B / Private Equity Jun 1, 2016 \\
\hline$\$ 1.25 \mathrm{M} /$ Angel Oct 15, 2010 & CrunchFund & Sherpa Capital & Saudi Arabia's Public Investment Fund \\
\hline First Round (Lead) & Data Collective & Valiant Capital Partners & \\
\hline Alfred Lin & Goldman Sachs & & \$1.15 B / Debt Financing Jul 7, 2016 \\
\hline Babak Nivi & Jeff Bezos & $\$ 600$ M / Series E Dec 16, 2014 & Morgan Stanley (Lead) \\
\hline Cyan Banister & Nihal Mehta & Baidu & Barclays PLC \\
\hline David Cohen & Signatures Capital & & Citigroup \\
\hline Founder Collective & Summit Action Fund & \$1.6 B / Debt Financing Jan 21, 2015 & Goldman Sachs \\
\hline Jason Calacanis & Troy Carter & Goldman Sachs & \\
\hline Jason Port & Tusk Ventures & & \\
\hline Josh Spear & & \$1 B / Series E Feb 18, 2015 & \\
\hline Lowercase Capital & $\$ 258$ M / Series C Aug 23, 2013 & AITV (Accelerate IT Ventures) & \\
\hline Mike Walsh & Google Ventures (Lead) & Foundation Capital & \\
\hline Mitchell Kapor & TPG Growth & HDS Capital & \\
\hline Naval Ravikant & Benchmark & Times Internet & \\
\hline \multicolumn{4}{|l|}{ Oren Michels } \\
\hline Scott Banister & \$1.2 B / Series D Jun 6, 2014 & \$1 B / Series F Jul 31, 2015 & \\
\hline \multirow[t]{2}{*}{ Shawn Fanning } & Fidelity Investments (Lead) & Bennett Coleman and Co Ltd & \\
\hline & BlackRock & Microsoft & \\
\hline$\$ 11$ M / Series A Feb 14, 2011 & Google ventures & Microsoft Corp. - Strategic Investments & \\
\hline Benchmark (Lead) & Kleiner Perkins Caufield \& Byers & & \\
\hline Alfred Lin & Menlo Ventures & \$100 M / Private Equity Aug 19, 2015 & \\
\hline First Round & Sherpa Capital & Tata Opportunities Fund & \\
\hline Innovation Endeavors & Summit Partners & & \\
\hline Lowercase Capital & Wellington Management & & \\
\hline Scott Banister & & & \\
\hline
\end{tabular}

Actually, a growing debate is mounting about the future role of venture capital, whose space within the equity financing industry may seem thinner or, worse, close to demise because of the pressure coming from the mentioned alternative sources of financing on both sides, namely, seed and late-stage investing.

In this review paper, we focus on the challenges as well as market opportunities available to venture capital, trying to shed light on the main features, investment policies and risk-return profiles of institutional and informal investors operating or obtaining access into the very early stage of the life cycle of SMEs. With respect to the complex and multidimensional nature of startups, our main contribution is to provide a comprehensive representation that could be useful for the identification of new and more effective fundraising strategies aimed at further incentivizing entrepreneurship and boosting innovation across countries with different stages of development and completeness of their capital markets, particularly the venture ones.

The rest of the paper is structured as follows. Section 2 briefly presents the major features and sources of differences among early stage companies. Section 3 focuses on business angels, highlighting their investment aptitudes and practices but also their 
major open issues. Section 4 presents the main features, strengths and weaknesses of equity crowdfunding, whereas in section 5, we discuss challenges and opportunities related to one major trend involving the venture capital industry, the emergence of large institutional investors that have been complementing their traditional asset classes with direct investments in startups. Finally, section 6 will summarize the relationships and the growth potential envisaged for the previously discussed sources of financing and will present suggestions for future research as well as for policymakers.

\section{Segmenting early-stage companies: scalability, funding gap, scope and growth potential}

When investigating the distinguishing features, the investment needs, the revenue model and the cash flow generation pattern of new ventures, one relevant issue mostly neglected by finance literature is the great deal of heterogeneity affecting startup companies.

First, startup companies do not all share the same intrinsic growth potential and, therefore, are not all considered a relevant target for professional formal equity investors. In accordance with the terminology widely used by professionals and venture capitalists, it is a matter of "scalability". In particular, scalability refers to the act of growing larger while keeping intact the ease with which the business is operated as well as the business's profitability. All companies are scalable to a given point, but some have to make significant changes to their business models to grow any further (due to high vs. low upfront investments, capital vs. labor intensive technologies, tailor made vs. standardized products, and so on). In a few cases, it is also possible that the entrepreneur is not able to adapt the company to the dynamic environment or is not able to understand these changing needs. Moreover, not all entrepreneurs have the desire and capability to scale up a large organization, preferring 1) comfortable living for themselves, family and friends, 2) majority equity stakes, and 3) low risk-and not profit maximizing - strategies. In the entrepreneurship literature, such entrepreneurs are qualified as "lifestyle" entrepreneurs as opposed to "growth-oriented"-or Schumpeterian - ones (Burns, 2001).

The equity gap - in the previous section, also labeled the "primary funding gap"represents a second problem that startups and especially early stage companies have to cope with. The typical monetary investment needed in the very early stages of a company's lifecycle is often limited not because of a lack of 'ambition' but because of the lack of 'marketability' of the company's output, which still has to be tested, eventually industrialized and promoted. Furthermore, the tangibility of the investment needs dramatically differs across companies and is very low for startups with a strong orientation to innovation and in which $\mathrm{R} \& \mathrm{D}$ investments represent a high percentage of their overall investment needs. The possibility of stimulating innovation and technology breakthroughs relies on the capability to offer concrete solutions to this primary funding gap (Hall and Lerner, 2010), whereas successive rounds of financing aimed at 
enabling the innovative companies to further develop the fruits of their previous R\&D investments and to fine tune a feasible and competitive business model ('secondary funding gap') provide a best match between venture capital investment policies and targets (Hellmann and Puri, 2000; Sohl, 2007; Kerr and Nanda, 2014; Kraemer-Eis, 2016; Wilson et al., 2018).

As far as the minimum ticket size of the equity investment is concerned, several studies show that young SMEs require a relatively small amount of capital, usually in the range between $€ 50,000$ and $€ 300,000$ (Sohl, 1999; Wong et al., 2009; European Commission, 2015; Landström and Mason, 2016; OECD, 2017), which in most cases excludes them from private equity and the venture capital's investment policies. Typically, venture capitalists, both US- and Europe-based, prefer to invest in highly innovative firms requiring higher minimum investment needs, usually over $€ 1,000,000$ (Manigart et al., 2002; Mason et al., 2013; Kaplan and Lerner, 2017; EY, 2017). Thus, there is often a disproportion between, on the one hand, the size of the investment needs of young new ventures, and, on the other hand, the monetary and nonmonetary costs faced by venture capitalists in order to screen, evaluate and monitor such an informationally opaque class of equity investments, ultimately making it not convenient to deploy financial resources under a minimum scale size.

Another major differentiating factor is the extension of the new ventures' competitive arena: since the very beginning, some companies, such as recently the fintech firms, have had the potential to rapidly scale-up their business and compete on a global basis, while other companies, such as many service companies and particularly companies in the tourism industry, have emerged with a geographical scope intrinsically limited due to their selection of a specialized and focused business model.

In summary, by recognizing the relevance of macroeconomic as wells as industry and firm specific factors, it is possible to argue that the growth potential, which is largely written in the DNA of the new ventures, is fed by the entrepreneurs' goals, commitment, abilities and orientation to innovation (Lerner et al., 2016; Hellman et al. 2017). The growth potential, in turn, is a major driver of the financing path available to a given company, also determining or strongly affecting the kind of investor accessible to the company and the follow-on alternative sources of funding after the first capital injection.

\section{The informal venture capital market}

One major alternative to venture capital that has emerged and consolidated over the last two decades is the so-called informal venture capital market, whose major actors are business angels (BA) and business angel organizations.

Often referred to as informal investors and acting alone or in a formal or informal syndicate, BAs are high net worth or affluent individuals, acting alone or in a formal or informal syndicate, who invest their own money in small unlisted companies with which they have no family connections, typically assuming a minority equity stake as well as 
becoming actively involved in portfolio companies (Mason, 2008). In fact, alongside capital injection, BAs provide valuable nonmonetary resources, such as industrial knowledge, management experience, mentoring, and personal networks (Harrison and Mason, 1992; Landström, 1993, Politis, 2008; Avdeitichikova and Landström, 2016). Their main role in the economy is to fill the previously defined primary funding gap between, on the one hand, the internal finance coming from the entrepreneurs and the friends and family tranche, and, on the other hand, the external finance raised from institutional VC firms, when the size of the average investment need is far too big for the former and far too small for the latter (Mason and Harrison, 2000). As a further proof of this, in many cases, angel financing can be structured as a loan that accrues interests over time and that, at maturity, converts to equity at a discount to the value of the first follow-on funding round led by an institutional investor (Wong et al., 2009; Cumming, 2012; Chemmanur and Chen, 2014).

According to the empirical evidence progressively emerging in the last two decades from research contributions investigating the informal venture capital market all over the world, different from the other main actors of the early-stage financing industry, business angels do not focus only on seed and start-up investments; they also acquire equity stakes in mature small companies, i.e., typically, companies that are managed by an executive included in their networks and that operate in industries the business angels know very well, as they may have already invested in it or previously succeeded in that industry as entrepreneurs (Kerr et al., 2014; Capizzi, 2015; Mason, 2016).

As for the BAs' investment practices, recent contributions emphasize, on the one hand, the high selectivity of their investment decisions as measured by the high rejection rates, which are mostly related to the perceived quality of both the entrepreneur and the management team (Mason, et al., 2016). On the other hand, in the due diligence and valuation of investment opportunities, their screening process gives a relevant role to personal and informal sources over formal sources of information, thus bringing subjectivity, personal relations and qualitative nonfinancial information inside the investment decisions (Harrison and Mason, 2017).

Another unique feature of the angels' operations is the method used for their investment's monitoring, which is based on what Bonini et al. (2018) refer to as "softmonitoring" mechanisms. Different from contractual-based monitoring mechanisms typically used by venture capitalists to reduce potential conflicts and the incentives for opportunistic behavior by entrepreneurs (Sahlman, 1990; Triantis, 2001; Kaplan and Stromberg, 2003; Gompers and Lerner, 2004; Chemmanur et al., 2008; Cumming, 2008; Wong et al., 2009; Erenburg et al., 2016), the monitoring mechanisms preferred by angel investors are non-aggressive and informal control mechanisms based upon a close postinvestment involvement in the relevant company through company visits, interactions with entrepreneurs, and other control techniques based on trust (Van Osnabrugge, 2000; Wiltbank and Boecker, 2007; Ibrahim, 2008; Wong et al., 2009; Goldfarb et al., 2013; Bonini and Capizzi, 2016). Furthermore, due to both the minority equity stake usually acquired by angel investors (Wiltbank et al., 2009; Kerr et al. 2014; 
Landström and Mason, 2016) and the abovementioned weak legal protection implied by their soft-monitoring mechanisms, the small deal of formal control is beneficial to the development and the duration over time of a trust-based relationship between the angel investor and the entrepreneur. This, in turn, could make it easier to involve venture capitalists and other institutional investors, who, on the contrary, will face uncertainty, information asymmetries and agency costs through contractual-based control and governance mechanisms, in the following rounds of fundraising. The scarce appetite of formal equity investors for target companies with complex underlying contractual relationships between the entrepreneur and a business angel has been clearly shown, directly implying that 'the startup's need for further funding from venture capitalists sets de facto limits on the terms of the angel investment contract' (Ibrahim, 2008). Furthermore, other contributing studies, by investigating the dynamic interaction between business angels and venture capitalists, revealed the existence of a chronological pecking order in the entrepreneurs' funding policies, leading companies to first access the informal investors and then to apply for equity capital from the formal ones, with the angels possibly remaining in the investee companies, though with minority equity holdings (Schwienbacher, 2009; Bruton et al., 2010; Chemmanur and Chen, 2014; Hellmann and Thiele, 2015).

On the other side, it is worth mentioning an alternative and highly promising theoretical framework, which assumes between business angels and venture capitalists, the existence of a substitution-based relationship rather than a complementary-based one. The underlying rationale is that the synergies - if any-enjoyed by VCs when investing in a target company after a prior angel-financing round may be more than offset by many other issues negatively impacting the future performance of the investment itself. First, the dilution of the angels' stakes as a consequence of the equity infusion run by the VCs has to be managed, which implies incurring transaction costs that could possibly impact the cohesion within the three typologies of stockholders. Second and connected to the previous argument, BAs and VCs have different utility functions that lead to heterogeneous investment policies for the holding period, the profitability target and, consequently, for the desired strategic priorities designed and pursued by the target company. Third, the entrance of VCs may lead to dramatic changes in the governance of the investee company, including the loss of board seats for BAs and new management suggested by the new formal investors, with the final effect of further reducing the limited control rights and decreasing the effectiveness of the angels' soft-monitoring mechanisms.

These arguments suggest the startup ecosystem is much more complex than that proposed by standard finance theory that is based on the standard paradigm of a company's life cycle and the consequent identification of the different sources of financing facilities associated with each stage, as depicted in the previous Figure 2. In accordance with such a line of reasoning, Hellman et al. (2017), analyzing the financial history over time of a sample of Canadian companies, found that a company funded by a given type of investor (business angel vs. venture capitalist) is likely to raise equity 
capital in subsequent follow-on financing rounds by investors of the same type and is less likely to be financed by investors of a different type.

In other words, though such a theoretical explanation has yet to be further developed and tested, the dynamic interaction between startups and their investors could be firmspecific and conditioned by their prior choices about the type of investor first providing equity capital, leading to a "multidimensional" ecosystem where startups have their own financing paths, different and possibly parallel to each other, based on unique combinations of the many different alternatives now available within the startup ecosystem (Bessière et al., 2018). We will return to discuss further possible consequences for startups in the following paragraphs after having better clarified the operating differences between the main types of investors considered in this paper.

\subsection{The rising role of angel groups and their contributions to the performance of startups}

While angel investors have a long history, angel investment organizations (AIOs) - or, herein after, angel groups - appear to be quite a more recent phenomenon: these organizations date back to the mid-1990s and have shown a striking positive growth rate in the last two decades, even though the recent financial crisis has dramatically affected the other segments of the capital markets (see Figure 3).

Figure 3 - Number of angel investor organizations in the 1999-2015 period

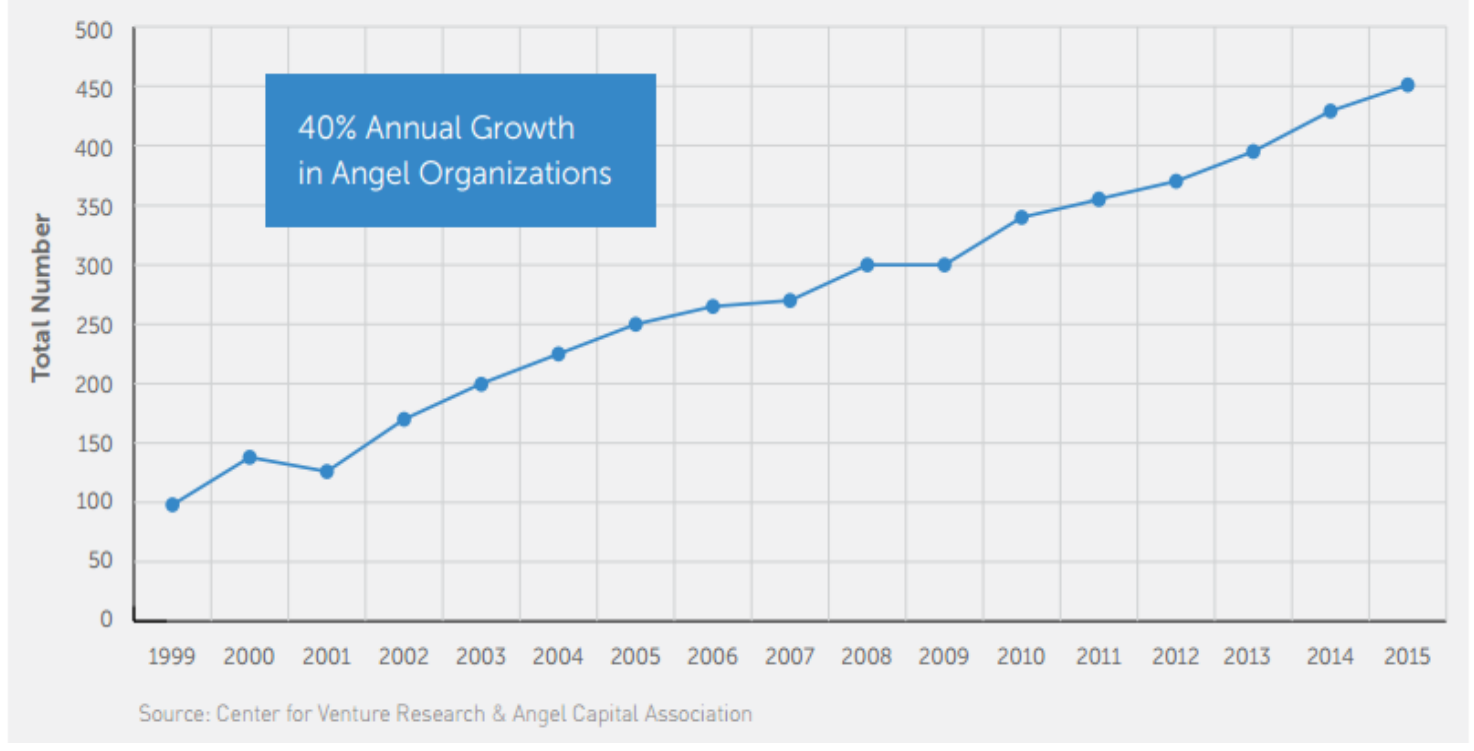

Angel groups are structured as semiformal or formal network of high-net-worth individuals, who regularly convene as a group to evaluate and invest in startups typically on a concentrated geographic region (Sohl, 2007; Paul and Whittam, 2010; Gregson et al., 2013; Mason, et al., 2013; Lahti and Keinonen, 2016; Bonini et al. 2018). 
These associations have grown to regional, national, and even continental proportions, increasingly differentiating among each other in terms of rules of engagement, internal structure, quality, variety, and cost of the services provided. Currently, there is a great deal of heterogeneity among angel groups, whose activities should not be confused with another emerging investment practice in the informal venture capital industry, that is, coinvesting. In fact, many angels may decide to coinvest in a given deal without joining an AIO or without belonging to the same angel organization. However, a single club deal can evolve, leading to the creation of an angel organization less formal and structured than an angel group and that is often referred to as a business angel network (herein after BAN).

The main difference between BANs and angel groups lies in the BANs' less stringent obligations and engagement rules for membership, such as limited or no fees, no minimum participation requirements, and no obligation to share due diligence costs (Mason et al., 2013). BAN members can join through a solicited or unsolicited basis and can collaborate in organizing pitching events, training, and mentoring activities, and coordinated lobbying efforts. Entrepreneurs are solicited to submit their proposals to the BAN through websites and other networking activities taking place inside the community. There is no (or there is limited) organized deal-group processing, and the angel organization does not make investments on its own or recommend investments to members; rather, each member decides whether to invest on a deal-by-deal basis, joining other investors and coinvestors and sharing preliminary valuations, due diligence, negotiations, and term sheets.

Different from BANs, angel groups may not remain neutral but, alternatively, they usually offer their associates the right to enjoy common services, including formal valuation and due diligence activities carried on in accordance with a predefined set of formal rules. Additionally, by signing investment term sheets negotiated and set within the group itself, associates are allowed by their angel group to invest alongside a single well-connected angel or to join an investment vehicle together with other members of the group.

Leaving aside their heterogeneity, one of the reasons for such an increasing trend of business angel organizations is the relevance and magnitude of the advantages these groups provide to their member investors. First, by coinvesting in a given deal with other investors, member angels can achieve the benefits of portfolio diversification, reducing their individual equity stakes in the invested ventures while maintaining an active involvement and providing value-added contributions. At the same time, a second further advantage is the opportunity for each single angel, by joining on a clubdeal basis a given investment opportunity, to make larger investments than those that would be possible to contract on a stand-alone basis.

Third, due to the larger size of their investment tickets, the angel groups typically are much more visible than solo investors are, allowing their members the possibility to benefit from a higher quality deal flow. Fourth, by sharing the cost of due diligence, contract designing, negotiating and closing, as well as the postinvestment monitoring 
costs, the overall transaction costs are reduced within the context of an angel organization.

Finally, a further significant advantage comes from the information and knowledgesharing effects taking place inside the community. The managers of the angel investment organizations (also known as "gatekeepers") organize periodic training meetings and pitching events aimed at stimulating the interaction between angel investors and entrepreneurs looking for funding (Ibrahim, 2008; Paul and Whittam, 2010; Brush et al., 2012; Mason et al., 2016).

Regarding the investment in the target ventures, there are no universally agreed on screening and funding procedures: every angel group follows its own rules and practices that have been proven over time to be effective and consistent with their members' characteristics, allowing, however, for flexible and discretionary investment decisions in a significantly informal context. In fact, independently from one another, group members often express their interest in a given deal without any kind of prior commitment to the angel organization, mostly basing their investment decision upon a personal assessment of the proposed project.

However, there is a pattern that seems to be a basic guideline in every angel group. First, entrepreneurs submit an application, which will likely include a copy of their business plan/executive summary, to the group. Then, an initial screening phase, performed by the organization staff, excludes a priori submissions that do not fulfill minimum requirements (e.g., companies seeking over-range investments). Firms that make it through this step are invited for a short presentation to a small group of members, followed by a question and answer session. Promising companies are then invited to present at a monthly meeting. Presenting companies that generate the greatest interest enter into a due diligence reviewing process. In the end, if the outcome of the in-depth analysis on the whole set of information dealing with the proposal is positive, companies have the chance to be funded after the signing and closing of the standard investment agreements, which, in some cases, are negotiated by a deal team consisting of a lead investor and some members of the management team of the angel group.

In the following Figure 4, the Tech Coast Angel, the largest angel network in the United States, is shown as an example of how an angels' group executes the investment decision process (Sudek et al., 2008; Kerr et al., 2014).

Among the numerous contributions investigating the transformation of the angel market in the last decade that has been led by the emergence of AIOs, there has been a promising research stream that has focused on the impact of angel investors on the investee companies - both in the US (Kerr et al., 2014) and worldwide (Lerner et al., 2016) - and that has attempted to disentangle the angels' selection effect from their value-adding effect.

Consistent with the literature on the role of private equity investors on the performance of the venture-backed companies (Lerner, 1995; Amit et al., 1998; Colombo and Grilli, 2010; Croce et al., 2013), the starting point of these studies has been the identification 
of an appropriate methodological approach aimed at examining the endogenous characteristics of the most successful companies compared to those of the lowest performing ones, possible determining the screening and funding decision of the investors. To both remove such endogeneity issues and to differentiate the value adding contributions of angel groups, over a sample of companies applying for funding, the authors of the two abovementioned contributions use a "regression discontinuity approach" to a predefined set of angel groups and achieve different outcomes: some companies were funded and other ones were rejected, though the rejected ones were similar to the former companies. More in detail, this methodology uses semirandom differences in the likelihood that a deal is funded as a way to build treated (the funded ventures) and untreated (the unfunded ventures) samples. By looking at the voting process taking place after the pitching events inside angel groups and relating the probability of a venture being funded to the number of BAs showing interest in a given deal, it is possible to identify the threshold where a critical mass of angels emerges around a deal, thus determining the feasibility or the rejection of the propose transaction. The authors then considered for the subsequent analysis only the "border groups", that is, the firms falling just above and below this threshold, once they had controlled for the similarity of the firms in the border region prior to their obtaining access to the angel groups.

A first major finding from this research stream proved and quantified the positive impact AIOs have on the growth and survival of the companies they fund. Both in the US (Kerr et al., 2014) and worldwide (Lerner et al., 2016) this result is consistent with different measures of performance, such as (i) the survivorship three years after the funding event, (ii) the likelihood of the funded venture to undergo a successful exit (IPO or M\&A) and (iii) the growth in employees, patents and web traffic performance. 
Figure 4 - Tech Coast Angels Investment process

\section{TCA Orange County Screening Overview}

Welcome to the \#1 Angel network in the US. We are pleased you are attending an Orange County screening session. The screening process is an important part of the TCA process. Typically, we have over 300 companies per year apply over the web for TCA funding. Approximately one third of these companies make it to the screening process which you are about to participate in. Although each year varies, we typically fund between 10 and 20 companies per year. TCA consists of 4 chapters, each facilitating the first three steps of the deal flow process a little differently. The overall deal flow process for TCA consists of 7 steps as follows:

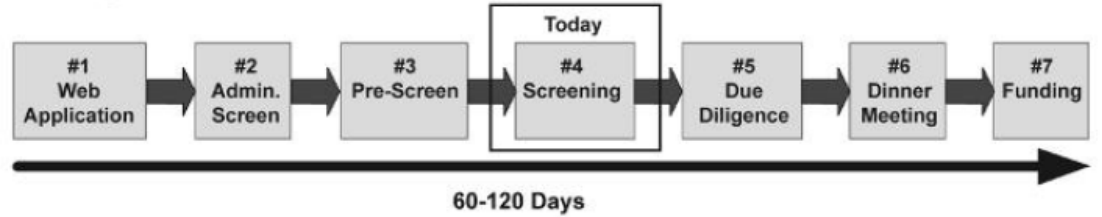

1. Web Application - Entrepreneurs apply to TCA on the Internet. This process includes filling out a 4 page overview of their startup venture.

2. Admin Screen - TCA staff perform a quick screen on the application to insure it is within the target area for a TCA venture. For instance, we typically fund between $\$ 250,000$ and $\$ 1$ million. If a company is seeking outside this range, typically they are not moved forward to pre-screen.

3. Pre-Screen - In Orange County entrepreneurs present a brief overview of their company to 3-7 TCA members. This includes 5 minutes of presentation and 25 minutes of informal questions and discussion with the TCA members. At the conclusion of this session, the prospective company is moved to screening, or given feedback why they may not be a good fit for TCA.

4. Screening-Typically 3 companies present at a screening. This consists of 15 minutes of PowerPoint and 15 minutes of Q\&A. After the Q\&A, we ask the entrepreneurs to leave the room and we discuss the company in private (typically it takes 10-15 minutes). The entrepreneurs are invited back into the room, and a designated member provides quick feedback. Typically, the companies present at all 5 chapters. Therefore, it is possible for a company to get little interest at one chapter, but enough interest at another chapter that will allow it to move forward to due diligence. In Orange County we utilize a moderator to facilitate the sessions. This is intended to help balance questions for our members such that a member will not dominate the Q\&A time. If you are a prospective member you are welcome to ask questions during the Q\&A portion of the presentation.

5. Due Diligence - A due diligence team is formed based on the number of interested members who signed up during the screening. A deal lead steps forward and helps coordinate the due diligence activities. Due diligence consists of verifying representations by the venture, customers, agreements, references, backgrounds, etc. The results of the due diligence process are posted on the TCA website (members only section), and if the results are positive, the venture moves forward to dinner meetings.

6. Dinner Meeting - Companies that pass due diligence present at monthly dinner meetings at each chapter. This allows them to get in front of members who might not have seen them at screening or were involved in the due diligence process. This is the opportunity for the entrepreneurs to garner enough interest by members to secure funding.

7. Funding - Funding occurs after there has been enough interest generated through dinner meetings and internal communication from the entrepreneur and deal lead. Members invest in deals individually, thus only a small percentage of members need to participate for the venture to secure funding. Typically, the minimum investment amount $\$ 25,000$.

Source: Sudek et al. (2008) 
However, a second striking finding is that only outside the US, angel funding seems to matter significantly for the ability of a firm to obtain follow-on financing. This result may suggest that in the US, due to the intrinsic high completeness and liquidity of the market for startup capital, prior angel funding is not an essential prerequisite for obtaining access to follow-on investment rounds and, thus, even companies turned down by angel groups are able to find alternative sources of financing.

A third key finding is that the typology of firms applying for angel funding is different across countries: compared to applicants in more entrepreneurship-friendly countries, pitching firms established in countries with a less conducive entrepreneurial environment are larger-sized and already revenue generating. ${ }^{4}$ However, despite their size and maturity, the firms in these markets seek a smaller amount of funding. A possible explanation, given the arguably scarcity of alternative funding options for entrepreneurs in such countries, is the tendency of firms to "self-censor" when applying to angel groups, consistent with the perceived higher risk aversion of BAs as well as when compared to venture capitalists, their having less background in assessing very early-stage investments.

Thus, on the one hand, an estimate of the expected magnitude of the aggregate impact of BAs, especially in entrepreneurship-unfriendly countries, is still an open issue for future research; on the other hand, little is known about the kind of evolution that is required to adapt the BAs' investment practices to the changing investment environment across nations.

Additionally, a final issue requiring a great deal of further investigation - as discussed in Bonini et al. (2017) - is the wide heterogeneity across angel investment organizations: some contributions make reference to angel groups, others to BANs, and others make reference more to ad hoc club deals that allow many angels not necessarily belonging to any given angel organization to join a given deal opportunity. We leave to future research the chance to shed light on the possible differential impact on the performance of new ventures made by different types of AIOs having peculiar association rules, membership and service structures alongside internal governance and management practices.

\subsection{Business angels and venture capitalists in the startup ecosystem: commonalities and unique features}

So far, we have discussed the main characteristics of a prominent pillar of the startup ecosystem alongside the impact of business angels and angel groups on the new ventures' performance.

Although it is difficult to obtain close to precise estimates on the informal venture capital market and a big piece of the picture is also "invisible" (Mason, 2008; Sohl,

\footnotetext{
${ }^{4}$ The authors use the following proxies as measures of entrepreneurship-friendliness of a country: (i) the depth of the venture capital market as a fraction of the domestic GDP, and (ii) the number of regulatory procedures while incorporating a firm (consistent with Djankov et al., 2002).
} 
2012; Landström and Mason, 2016; Edelman et al., 2017) due to the fact most angel investments are made on an individual basis and thus are not subject to regulatory disclosure requirements, recent survey estimates suggest the total size of angel investments is now close to that of venture capital in the US, in Europe and increasingly in many other countries as well (ACA, 2016; EBAN, 2017; Kraemer-Eis et al., 2017; InvestEurope, 2018; OECD, 2017).

Indeed, one major reason underlying the success of BAs is that they share many of the positive features of VCs. First, they provide equity financing to early-stage companies or, to some extent, later stage ones, although these companies may not be eligible to obtain access to public sources of financing. Second, they accurately screen their investments by undertaking intensive due diligence, though in most cases, not by using external advisors but rather by leveraging their experience and industry knowledge as well as the information-sharing process taking place inside the AIOs (Bonini et al., 2018). Third, BAs are keen to serve as mentors and, sometimes, outside directors for the funded ventures, thus actively supporting the corporate strategy and operations. They may also provide entrepreneurs with other nonmonetary contributions, such as sharing their reputation within the financial community, their knowledge of the industry and their network of relationships with future company stakeholders. Finally, as previously mentioned, they monitor their investments, thus disciplining the entrepreneurs, though using less formal and contractual-based mechanisms, preferring instead non-aggressive soft control mechanisms, such as company visits, informal meetings with the entrepreneur and other trust-based types of interaction.

Beyond such commonalities, BAs have a unique feature distinguishing them from VCs: they invest a percentage of their own personal wealth, making them less prone to the agency problems widely documented in the literature regarding venture capital (Fried and Hisrich, 1988; Sahlman, 1990; Gilson, 1998; Gompers and Lerner, 1999; Kaplan and Stromberg, 2003; Smith, 2005; Cumming and Johan, 2013).

The fee-based compensation structures of the general partners or the asset managers of a venture capital fund are now widely accepted. On the one hand, these structures may reduce both information asymmetries and agency costs between the investors and the fund managers, by realigning the managers' incentives; on the other hand, these remuneration mechanisms may lead to excessive fundraising, to suboptimal investments and investment decisions and, furthermore, to cases of misevaluation and overfunding of the portfolio companies during the fund holding period (Gompers and Lerner, 2001; Metrick and Yasuda, 2010; Chung et al., 2012; Wang et al., 2012; Robinson and Sensoy, 2013; Sensoy et al. 2014).

It is reasonable to argue, though yet to be adequately formalized and tested, that the kind of postinvestment active involvement alongside the trust-based relationship established between BAs and entrepreneurs play a significant role in offsetting some major issues affecting many capital markets across nations: the lack of legal protection for minority shareholders and, consequently, the thinness of such markets (La Porta et al., 1998; 2000; 2013; Djankov et al., 2002; 2008). 
However, because business angels are not professional investors and their investment practices in many cases are peculiar, subjective, and lacking formal due diligence (Ibrahim, 2008; Mason et al., 2013; Bonini et al., 2018), it is very clear there are relevant challenges also on the angel investors' side. Relying on informal investors might lead entrepreneurs to be exposed to idiosyncratic funding risks either because BAs themselves over time might be affected differently by idiosyncratic liquidity shocks than formal investors are or because BAs may change their opinions more frequently about what projects to fund. Additionally, angels might not be prepared to invest in truly radical high-growth projects since they are usually more risk averse than institutional investors are due to the angels' assumed lower portfolio diversification. They are also not supposed to have the required professional expertise to evaluate disruptive technologies or complex ventures operating in many different industries (Mason and Harrison, 2004; 2008).

Therefore - as discussed in Mason (2018) in this same special issue - to increase the effectiveness of this early-stage segment of the capital markets without sacrificing its main peculiarities and value-adding contribution to startups and to growing SMEs, much has to be done by public policies to encourage the development and professionalization of angel markets.

\section{The impact of crowdfunding on the startup ecosystem}

The most recent innovation within capital markets and particularly within the entrepreneurial ecosystem is the possibility of raising funds through crowdfunding campaigns.

The concept of crowdfunding has existed for long time, and political campaigns are one of the earliest examples of its potentiality, allowing the raising of funds by obtaining access to a large number of possible sponsors interested in joining a given project with their relatively limited monetary contributions. Among the many other examples, cases of successful crowdfunding campaigns deal with artists financing concerts, statues, publications, or producers financing movies or sport teams raising funds to join major competitions. Currently, crowdfunding is also used to finance investments in many industries, such as energy, entertainment, food and beverage, ICT, real estate, ecommerce and the sharing economy (Hervè et al., 2016; Massolutions, 2017; Statista, 2018).

Supporting the recent exponential growth of this alternative source of funding and facilitated by the technological innovation of Web 2.0, the development of internetbased online platforms has contributed to making crowdfunding simpler, more scalable, cost efficient and more visible and attractive to retail investors (Kleeman et al., 2008; Lambert and Schwinbacher, 2010; Griffin, 2013; Bruton et al., 2015). Platforms, such as KickStarter, Pebble Smartwatch, Indiegogo and Crowdcube - just to cite some of the most well-known and established ones, capable of launching successful campaigns intercepting millions of dollars - are currently the most visible development that, 
representing the difference between old and modern crowdfunding, is now a prominent pillar of the entrepreneurial finance ecosystem.

In fig. 5 (insert) and 6 (insert), it is possible to observe over the last decade this alternative finance market's tremendous growth, especially when compared to that of both the venture capital and angel finance markets.

Leaving a review of the many different notions and definitions of crowdfunding to the rising literature (Harrison, 2015; Giudici, 2016; Pichler and Tezza, 2016; Cumming and Hornuf, 2018; Wallmeroth et al., 2018), it is worth starting from the definition of Belleflamme et al. (2013 to identify the major constituting elements and players: "crowdfunding involves an open call, mostly through the Internet, for the provision of financial resources either in the form of donation or in exchange for the future product or some form of reward and/or voting rights".

By elaborating on such a definition, it is easily to deduct that crowdfunding typically involves at least the following three key players: (i) the entrepreneur (the "campaigner"), who is looking to raise money for a project or venture; (ii) the crowd of people who pool relatively small contributions to support innovative projects (the so-called "backers"); and (iii) the platform, which hosts the campaign and allows the fundraiser and the crowd to meet.

Fig. 5: Trend in Equity Crowdfunding, Venture Capital and Seed Stage Financing

\section{Equity-based Crowdfunding in the Context of VC/ Equity Investment in the UK (2011-2015)}

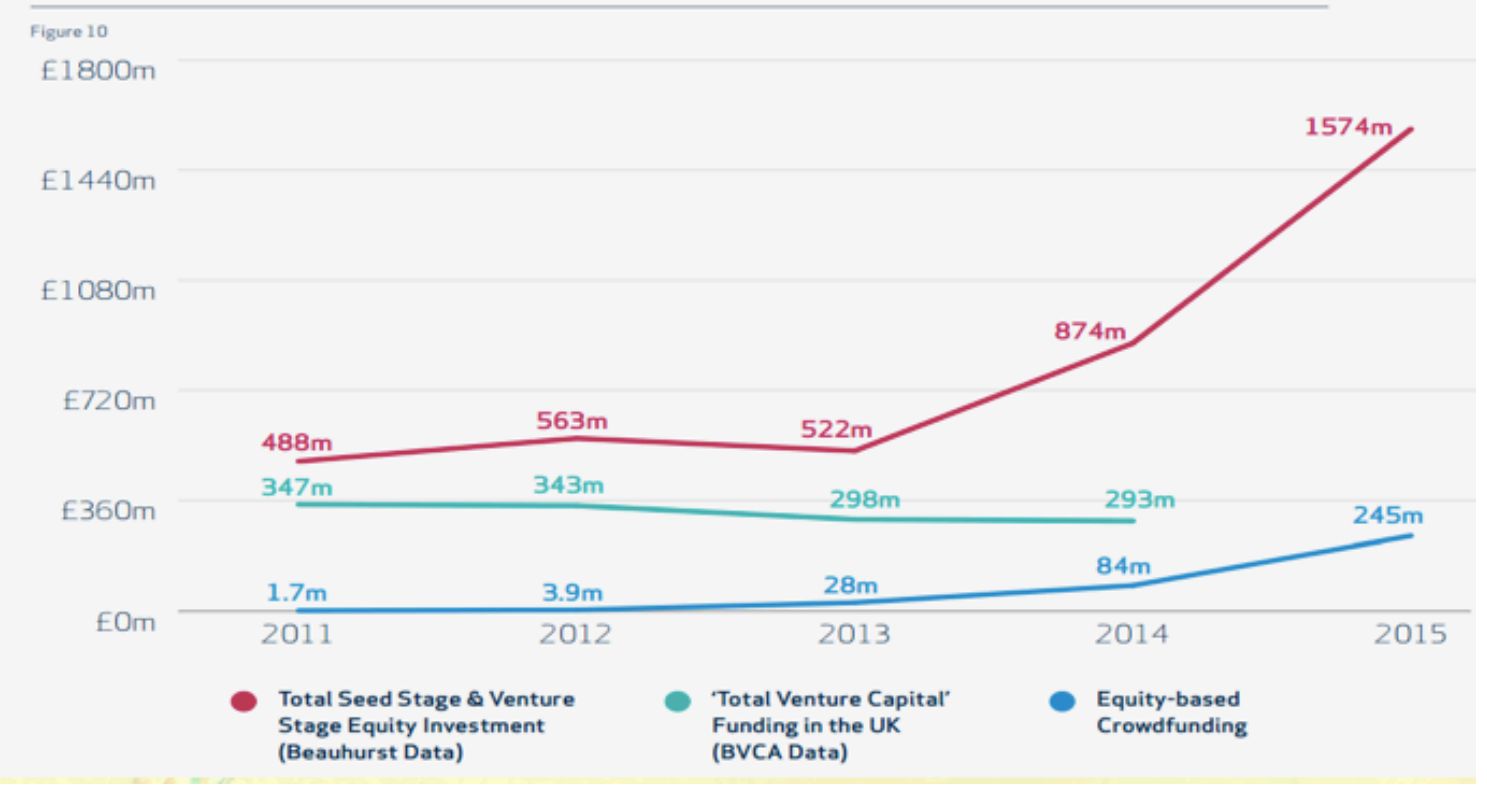

Source: Zhang et al. (2015) 


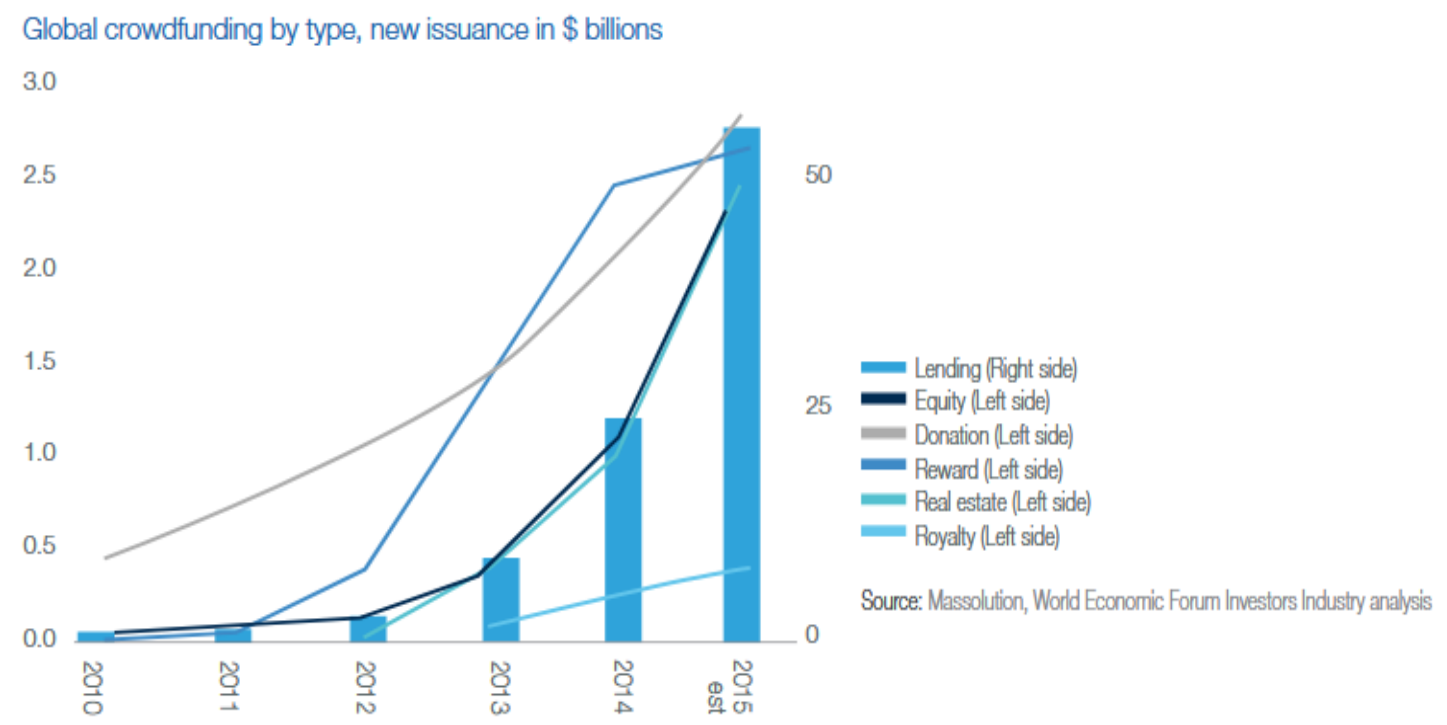

Fig. 6 Trend in Crowdfunding: breakdown by typology of crowdfunding

Looking at the motivation behind the entrepreneur's decision to run a crowdfunding campaign, on top of meeting specific funding needs, there is the willingness to replicate the previous campaigners' successful experiences or the opportunity to use the internet to either test the market for a future product or to easily and quickly reach a vast multitude of potential customers (Gerber et al., 2012; Mollick, 2013). Furthermore, a successful campaign can increase the probability to complete follow-on financing rounds from more traditional sources of funding (Leboeuf and Schwienbacher, 2018).

For an entrepreneur, the choice to adopt crowdfunding as a fundraising method may be a consequence of being refused by other investors, such as angels, or simply because the amount of money needed for their activity is too high to gather from family and friends and too low to be considered by the bigger institutional investors.

However, on top of providing small business with an alternative to obtain debt capital or equity capital from more established segments of capital markets, thus reducing the funding gap between available seed capital and the startups' funding needs, crowdfunding brings many other advantages. As already seen, it can serve as "proof of concept": achieving high goals in a crowdfunding campaign allows the campaigner to obtain publicity and to demonstrate a product's potential. The generation of rumors about products that are still very early in the development process may help in attracting customers, employees and investors. Further, success seems to be linked with a higher likelihood of obtaining business partnerships and of building a strong customer base. Finally, crowdfunding can support efforts to develop prototypes, while preserving equity for later-stage market strategies (Gerber and Hui, 2013; Belleflamme and Lambert, 2014; Kuppuswammy and Roth, 2016).

One well-known case to consider as an example of the abovementioned goals is the "Pebble smart watch" campaign. Pebble is a digital watch designed by Eric Migicovsky 
and developed by Pebble Technology Corporation. After many venture capital firms discarded the deal because of the perplexity upon the market acceptance of the product, a crowdfunding campaign was set on Kickstarter. Though the original funding target was set at 100,000 USD, in a very short time, the campaigners realized that the project, having achieved a significant following, raised over 10 million USD, with approximately 68,000 potential customers. Thanks to the performance of the crowdfunding campaign, Pebble was able to receive a further investment from the startup incubator "Y Combinator".

As for the backers' motivations, a preliminary distinction has to be made regarding the fundraising mode and the kind of compensation expected (Cumming et al., 2016). Dealing with the fundraising mode, on the one hand, there are crowdfunding platforms allowing the flow of funds according to the rule "all-or-nothing", meaning the campaigner will obtain financial resources only in case the project is able to reach the declared funding goal; otherwise, the raised capital will be returned to the investors; on the other hand, there are crowdfunding platforms functioning according to the "keep-itall" rule, implying the entrepreneur will receive all the money raised, regardless of whether the project was able to meet its funding goal. Kickstarter is an example of an "all-or-nothing" platform, whereas Fundly is an example of "keep-it-all platform"; Indiegogo, instead, offer campaigners the possibility to choose between the two fundraising modes.

As for the kind of compensation provided to the backers, it is possible to distinguish the categories of crowdfunding models described below. (Bradford, 2012; De Buysere et al., 2012; Harrison, 2013; Griffin, 2013; Pichler and Tezza, 2015).

- Donation crowdfunding is designed for investors not expecting direct returns in exchange for their monetary contribution. This crowdfunding model does not present any type of financial outcome for the investor and may involve an intangible nonmonetary reward, such as a thank-you email or a citation in a movie or DVD. When the project deals with humanitarian or philanthropic purposes and the campaigners are mostly not-for-profit organizations and charitable organizations, this might be referred to as "social lending" model.

- Reward crowdfunding consists of individuals giving their money to a project or business with the expectation of receiving a nonfinancial reward in return, such as goods or services at a later stage. A common example is a project or business offering a unique service or a new product or a ticket for a sport or an art exhibition. This form of crowdfunding allows companies to start their go-to-market strategy with orders already on the books and with their cash flow secured, which can be major issues for new businesses.

- Pre-purchase is a particular form of reward-based crowdfunding model that gives investors the possibility to pay in advance for a product or service they would be willing to buy immediately had it been available for sale; as soon as the production is completed, the backers - who are also the final customers-will receive the product at a special discount in a kind of premarketing stage as a compensation for 
helping the entrepreneur to develop a new product or service.

- Peer-to-peer lending, sometimes called crowdlending, is a direct alternative to a bank loan with the difference that, instead of borrowing from a single source, companies can borrow directly from a large number of individuals who are ready to lend in exchange for a financial return constituted, as in the case of a standard arm's length bank debt, by payments of the periodic interest plus the principal at the maturity of the loan itself. In some cases, crowdlenders often bid for loans by offering an interest rate at which they would be available to lend. Borrowers then accept loan offers at the lowest interest rate. Internet-based platforms are used to match lenders with borrowers. Due diligence is carried out for each loan request, as crowdfunding platforms have a duty to protect both the businesses' and the investors' interests. Platforms normally require financial accounts and a trading track record.

- Equity crowdfunding, also called crowdinvesting or securities crowdfunding, consists of selling a stake of the endeavor to a number of investors looking for a financial return in the usual form of dividends and/or capital gains. Depending on the enforcing regulation in the different countries dealing with the sale of securities, backers entitled to obtain access to such a funding model could be only "accredited" ones or also "unaccredited" ones; in the latter case, this implies nonprofessional and less sophisticated investors who are not looking for just financial returns. The solicitation of the investors might take place without or with a "light" version of a securities prospectus and does not imply the involvement of advisors offering underwriting services. The securities could be common shares, but they could also be preferred shares, shares with limited or no voting rights and mezzanine-finance instruments that in most cases would be convertible debt.

The third fundamental player of a crowdfunding scheme is the platform connecting the supply and demand for seed capital. Although still little is known about the contribution of the many kinds of truly heterogeneous platforms arising all around the world to the performance of the overall funding process, two major issues have been extensively investigated: the revenue source and the management of asymmetric information (Belleflamme et al., 2015). For the revenue sources, it is possible to distinguish (i) transaction fees charged on the whole amount raised, (ii) charges for the additional services rendered, such as the payment or advertisement services, (iii) interest earned on committed capital by the investors plus, in a number of cases, (iv) a subscription fee paid by the investor when completing the registration on the platform. One major issue affecting crowdfunding deals is the impossibility for the crowdinvestors to rely on the same standard mechanisms traditionally adopted by capital markets and financial intermediaries to manage ex-ante and ex-post asymmetric information, leading to both selection and monitoring issues. Many platforms try to adequately manage information asymmetries by the following methods: performing screening activity; extracting and disclosing signals to the market - such as, for example, the campaigners' 
social capital and reputation; providing sophisticated investors exclusive access to investment opportunities; stimulating syndicated investments; monitoring on a regularly basis the development of funded projects; deferring the money transfer to entrepreneurs; and providing investors with risk management contracts hedging specific risks (Mollick, 2014; Belleflamme and Lambert, 2015; Belleflamme et al., 2015; Iyer et al., 2016; Hornuf and Schwienbacher, 2018; Lambert et al., 2018; Vismara, 2018).

However, little is still known about the crowdfunding campaigns' performance and the determinants of success as well as about the investment decision-making process of the crowd (Wallmeroth et al., 2018). The first preliminary evidence seems to show the crowd prefers investments opportunities that are not too complex, therefore not requiring a great deal of ex-ante costly due diligence: a major driver of the investment decision may be constituted by the signals and exchange of information among the backers taking place on the internet during the campaigns (Ley and Weaven, 2011; Moritz et al., 2015; Hornuf and Schwienbacher, 2018; Block et al., 2018). Focusing on the determinants of success of a given crowdfunding campaign, some recent contributions point out the role played by personal networks and social capital, project quality, pitch quality and the geographical distance from investors as major drivers affecting the likelihood of success of a campaign (Mollick, 2014; Colombo et al., 2015; Hornuf and Schmitt, 2016; Signori and Vismara, 2016). Other factors seemingly related to the positive performance of a crowdfunding campaign deal with the limited size and duration of the funding campaign ( $\mathrm{Li}$ and Martin 2016) as well as with the frequency of contributions by backers (Cordova et al., 2015)

\subsection{Major challenges and open issues in crowdfunding}

As for any other funding mechanism in the capital markets, affecting crowdfunding, there are a number of challenges and problems that if not adequately addressed, may possibly affect its future growth and consolidation (Wallmeroth et al., 2018).

First, a crowdfunding campaign may fail to reach its funding target, implying either the impossibility to run the scheduled investment or, worse, in the case of the all-or-nothing platforms, the need to return the capital raised back to the investors. Moreover, considering the public visibility on the web platforms of project outcomes, an unsuccessful campaign could also lead to an increased difficulty in obtaining access to other segments of the capital markets.

Second, given that project backers are usually less sophisticated and inexperienced investors, when performing due diligence and screening the investment opportunities, they may not invest based on the same amount of background experience or with the expertise of professional investors, such as venture capitalists or angel investment organizations. Crowdfunding may be affected by a selection issue, implying in many cases that it is relatively unclear whether many of the funded companies would have been better off if they had failed early or if, missing the minimum requirements to evolve into a performing and growing venture, they had not started their operations at all. 
For example, before being shut down by the SEC in 2015, a Nevada based company Ascenergy raised $\$ 5$ million on crowdfunding sites with the promise of creating an oil and gas business. According to the SEC, at the time it was shut down, the company hadn't made any investment in the oil industry nor finalized any contract with the clients as claimed in its fundraising campaign but rather had spent the raised capital on the founders' personal expenses.

Third, in some cases, an apparently successful campaign may lead to overfunding, meaning the capital raised is well above the funding goal (Mollick, 2014). Such a scenario may be the outcome of a lack of the campaigners' financial background and therefore poor business planning skills but, on the other hand, may depend on a kind of misunderstanding of the nature of crowdfunding itself by the backers, who may consider the platform a sort of shopping website for purchasing or preordering new products. As such, they seem to ignore the risks linked with those campaigns, such as the possibility that the project may fall apart or be delayed, especially if the entrepreneurs have not adequately structured the organization as well as the operations consistent with the high and unexpected volume of capital raised. In both cases, a possible effect is that an apparently successful crowdfunding campaign does not necessarily evolve into a successful business, as the "Coolest Cooler" case demonstrates. The Coolest cooler project, which was posted on Kickstarter in 2014, offered a "souped-up cooler" complete with Bluetooth speakers, a blender, and USB charger. It started with a funding goal of $\$ 50,000$ and soon exceeded its goal, receiving over $\$ 13$ million from over 62,000 project backers. However, due to drastic changes in the scale and unexpected manufacturing issues, the production incurred relevant delays, leaving two-thirds of the backers two years later without the Coolest Cooler. The following sense of disappointment and outrage makes it clear many backers had viewed their investment basically as a purchase of the product.

As a fourth problem affecting crowdfunding, it has to be underlined that in addition to the previously mentioned selection issue, the lack of experience, business and financial knowledge as well as a lack of a network of relations may generate a competitive disadvantage against VCs and BAs also in the postinvestment phase because of the lower nonmonetary contributions the backers may provide to the target companies, thus impacting the company's value creation path.

Additionally, the crowd may not have the adequate background and cognitive orientation required to understand and select radically innovative projects: it's not a problem of information asymmetry but rather an issue of the correct process and assessment of the information posted on the platform and focused on a given innovative project. For instance, Chan and Parhankangas (2017) show that crowdfunding campaigns focused on products incorporating incremental innovation are successful, whereas campaigns dealing with radical innovative products have a high probability of failing to reach their funding goals.

Sixth, investors might be exposed to significant liquidity risks due to the lack of an officially regulated secondary market, creating a situation which allows the backers to 
easily and quickly sell the stakes in a venture bought when joining a given crowdfunding campaign (Kirby and Worner, 2014; Bradford, 2018)

A final issue, which does not necessarily imply fraudulent behavior, is the possible plagiarism risk that has emerged from the internet-based, public nature of crowdfunding: it is not always possible to protect with patents or to enforce property right mechanisms for every product or idea posted in a web platform and to thus prevent other internet users from becoming competitors and maybe starting their businesses well earlier than the date when the original idea developer manages to enter into the market (Valanciene and Jegeleviciute, 2013). That is the reason why information disclosure requirements that are too strict could disincentivize many potential entrepreneurs and small businesses from even starting crowdfunding campaigns, as they may feel they do not have the possibility to prevent late movers from gaining access to and imitating their idea.

\subsection{Fraud and Regulation in Crowdfunding across the world}

One of the biggest issues potentially affecting crowdfunding campaigns is fraud, and because of its relevance, one major stream of contributions in the emerging research field of crowdfunding deals with regulations across countries and the relationship between specific regulatory requirements and the growth and performance of crowdbacked companies (Kirby and Worner, 2014; Hornuf and Schmitt, 2016, Armour and Enrique, 2017).

Fraud in crowdfunding may stem directly from the already mentioned great deal of information asymmetry affecting such an innovative segment of the capital markets, leading to cases where the campaigner hides the true financial status of the funded venture or uses the money raised for purposes different from those disclosed to the backers. For example, a recent survey of compliance by CrowdCheck found that approximately $40 \%$ of companies on these sites did not have their financial results audited or certified, falling well below the basic rules set down by the SEC (Popper, 2017).

A further typology of fraud is intrinsically related to the internet-based nature of the platforms and might give rise to identify theft, money laundering, data-protection violations or terrorism financing. The problem with this class of fraudulent behaviors is that fraud is observable only on an ex-post basis and the observation is limited to the detected cases (Wang, 2013; Hainz, 2018).

One fundamental safety net to protect investors in the capital markets is represented by regulatory authorities, who in terms of transparency and information disclosure, are entitled to set ad hoc rules that companies issuing securities have to be compliant with. However, in the case of crowdfunding, given the limited ticket size of a given campaign, it would be too expensive for issuers to sustain the compliance costs of fully applicable ordinary securities regulation. Hence, across different country jurisdictions, in the last few years, we have been experiencing alternative regulatory measures ultimately aimed at incentivizing equity crowdfunding by relaxing the rigor of ordinary securities 
regulation (Pope, 2011; Weinstein, 2013; Armour and Enriques, 2018a)

For instance, in the US in 2012, the Obama administration launched the JOBS (JumpStart Our Business Startups) Act, whose "Title II" rule provided special exemptions to campaigners running unregistered internet offerings targeted to "accredited" investors (institutional investors and high net worth individual investors who were deemed capable of understanding the risks from financial investments or, at least, of affording the cost of access to financial advisors) and delegated to platforms the burden to check the quality of the financial information disclosed by funded companies and their compliance with the rules set down by the regulatory authorities. Since then, several platforms have progressively better structured their operations, implementing alternative solutions to avoid adverse selection problems and to ensure the quality of the offerings in terms, at least, of self-imposed disclosure requirements (Armour and Enriques, 2018b). Furthermore, successful Title II platforms are starting to behave more like traditional VC firms in their screening, investment and monitoring policies. For example, OurCrowd pools money from investors into special purpose vehicles and creates funds focused on sectors, regions, or growth phases. Consequently - as observable from figure 7 - the number of Title II crowdfunding campaigns has decreased over time, but the dollar value has increased. This may have also happened because the higher selectivity of the platform investors made investors more confident, numerous and available to invest larger amounts.

At the end of 2016, the SEC added to the JOBS Act the Title III rule, which finally went into effect on May 2016. Under Title III, subject to a certain degree of business and financial information disclosed to both the crowdinvesting platform and the retail investors, private companies are allowed to solicit funds up to 1 million USD from unaccredited investors. It is still forbidden, however, for platforms to structure special purpose vehicles in a manner similar to the way the private equity funds and the angel investment organizations structure vehicles to pool together individual investors' savings (Oranburg, 2015). Furthermore, the issue of the previously mentioned trade-off between the volume of information disclosed and the plagiarism risk still remains open: particularly for small businesses needing entrepreneurial secrecy, this situation could be potentially high and penalizing.

Figure 7 - Number and value of Title II crowdfunding campaigns

\section{FUNDRAISING UNDER TITLE II}

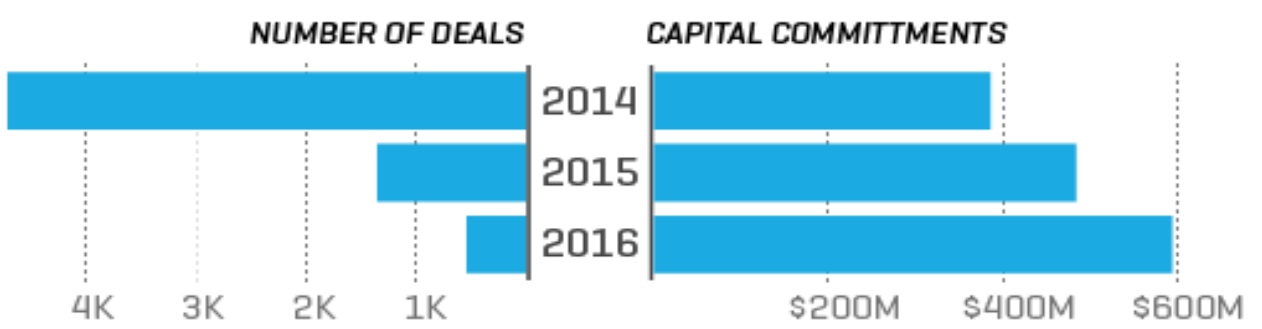

Note: To make a fair year-over-year comparison, deals and their value were totaled 
Source: Quittner (2016)

In addition, in Europe, the regulatory bodies dealing with securities' sale and trading have been progressively changed in order to favor the growth of equity crowdfunding, though currently, there still is not a unified regime applicable to the sale and underwriting of securities; rather, there are a mix of different domestic regimes, partly harmonized by the EU Prospectus Directive. On the one hand, EU member States were provided partial exemptions from current regulations on financial services (MiFID II) when dealing with small sized equity offerings, dispensing the requirement for issuers to comply with ordinary security regulation. Such exemptions made it possible to stimulate internet-based crowdfunding campaigns and to target equity offerings to both professional and retail investors. On the other hand, crowdfunding platforms are required to screen issuers' quality and to assess whether a given investment is appropriate for the investors. However, there is a great deal of flexibility for platforms in setting the appropriate screening mechanisms, leading to significant heterogeneity among European platforms in terms of operations, contract designing and offering procedures. For instance, some platforms only list companies simultaneously backed by business angels and retail investors, while some other platforms offer to the crowd the same contractual protection devices typically used by venture capitalists, such as preemption rights, veto rights, tag-along rights and so forth (Armour and Enriques, 2018b) Outside Europe and the US, one country experiencing an explosive growth in crowdfunding is undoubtedly China (see figure 8), where the first platforms appeared in 2011. The high number of projects looking for seed capital matched with the increasing supply of available financial resources coming from the crowd progressively shifting from a savings-oriented to an investment-oriented attitude boosted the crowdfunding campaigns, making it the largest crowdfunding market in the world (Liang, 2015).

The quick growth of such an alternative funding channel came at the cost of some relevant cases of fraud because of the much lower regulatory burden in China compared to that in other countries. At the same time, in a context of insufficient regulation, the platforms failed to both perform their screening role and to disclose adequate levels of information on the quality of the listed ventures to the backers.

An interesting example is the crowdfunding platform Ezubao, first launched in 2014 and becoming in a short time one of the ten largest $\mathrm{P} 2 \mathrm{P}$ lending platforms in China. Approximately 900,000 individual investors lost collectively $\$ 7.6$ billions, with an estimated $95 \%$ of all the Ezubao borrower listings reported to be fraudulent: in this 
case, it's clear the investors' money was used by top executives to enrich themselves.

This type of case, among others, contributed to the tightening of the regulations in the industry by the end of December 2014: now, the current crowdfunding regulation, which is unfortunately still a draft regulation, limits investments to accredited investors However, the need for still tighter-and official-regulation remains a major challenge in China: a total of 43 Chinese platforms were closed between 2015 and 2016 due to fraudulent fundraising, misrepresentation, internal conflict and lack of funding (Lin, 2017).

Figure 8 - Crowdfunding trend in China (breakdown by typology)

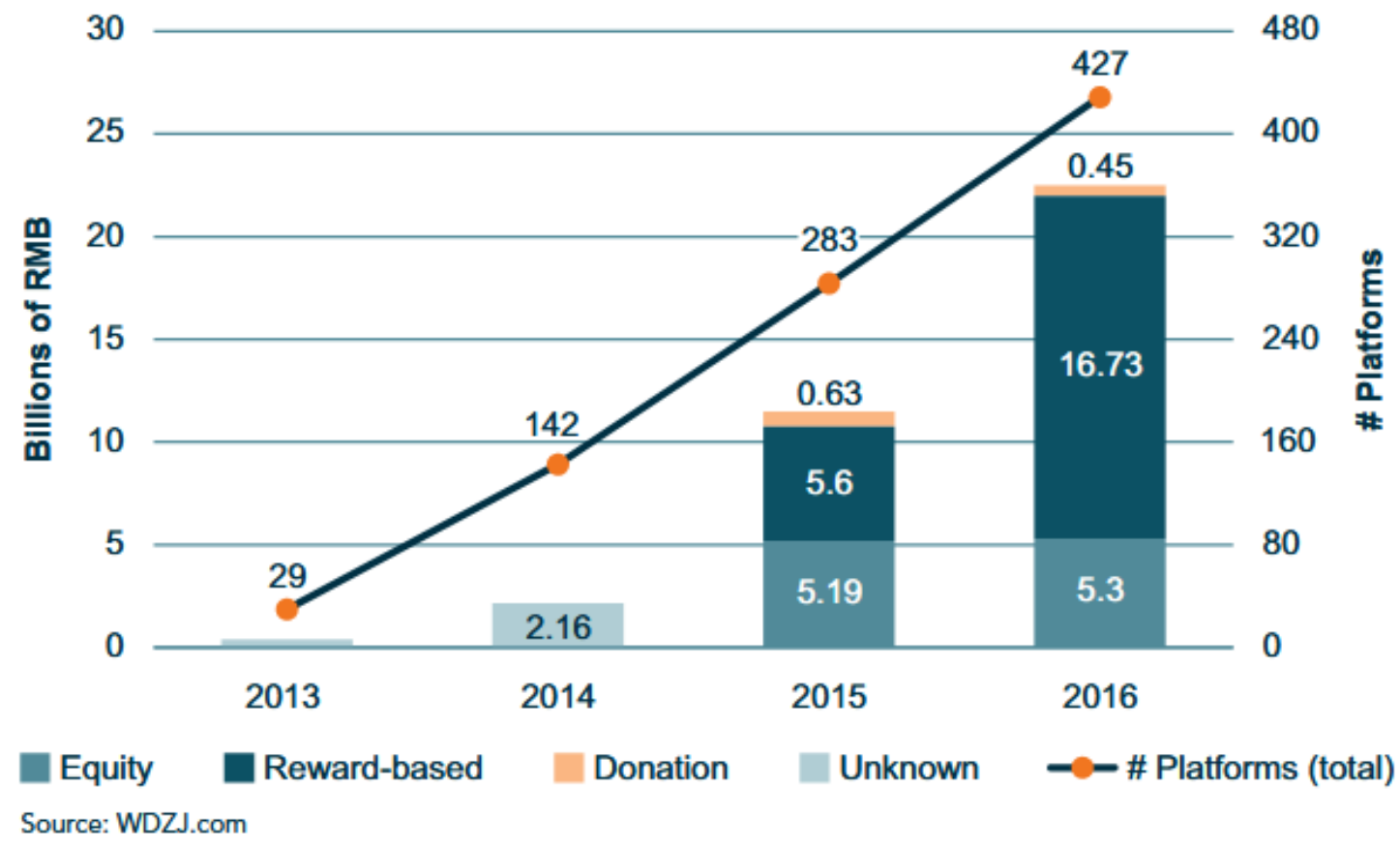

Summing up, the extent to which the crowdfunding market should be regulated remains an open issue depending on the specific choices made by policymakers who, on the one hand, have to balance between the need to limit information asymmetries and the prevention of fraudulent behavior with, on the other hand, the opportunity to relax standard regulations on the sale and trading of ordinary securities. Research on this topic is proceeding but will only in the next few years presumably lead to unambiguous results and policy suggestions to be implemented on a homogeneous basis all over the world (Bruton et al., 2015; Fraser et al., 2015; Dushnitsky et al., 2016; Klöhn et al., 2016; Cumming and Vismara, 2017).

\section{Direct investing and the mutual funds industry: the}




\section{disintermediation of the venture capital and private equity funds?}

In addition to business angels and crowdinvesting, another typology of investments experiencing a continuous growth over the last few years is constituted by institutional investors undertaking direct investments in small unlisted ventures, therefore bypassing the traditional closed-end fund structure of venture capital and private equity funds (Fang et al., 2015). Figure 9 shows the relevant increase of shadow capital (defined as coinvestments, direct investments, and separately managed accounts), accounting in 2017 for almost 33 percent of the estimated total volume of capital raised on a worldwide basis by the mutual funds industry.

Figure 9: Growth trends for shadow capital and traditional fund investments

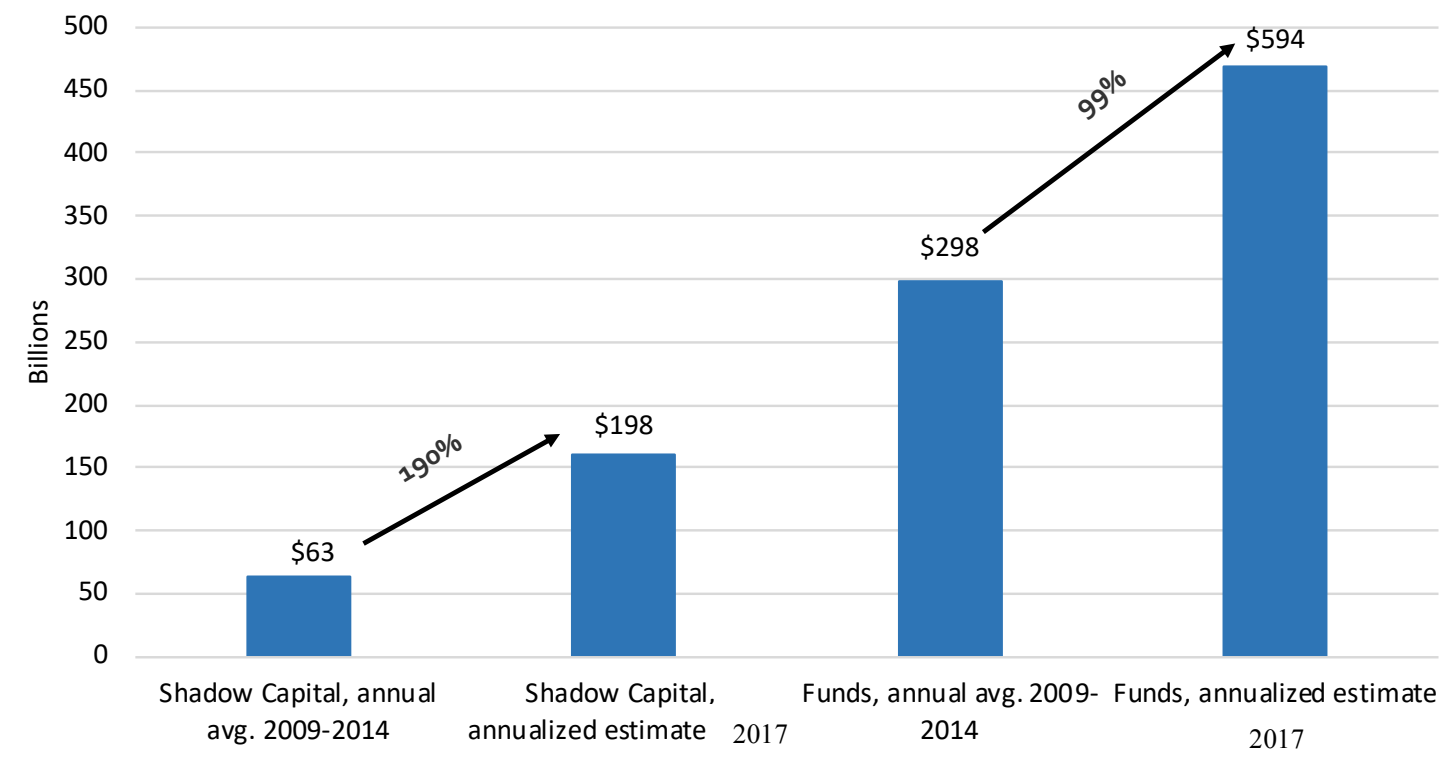

Source: Triago (2018)

In the traditional direct investing setting, institutional investors-also labeled as limited partners (LPs) - such as sovereign funds, family offices, funds of funds, foundations and endowments, insurance companies and even pension funds, subscribe to shares of private equity funds that are managed by specialized investors, the socalled general partners (GPs), who are responsible for the whole investment process, including deal selection, negotiation and deal contracting, monitoring and exiting (Gompers and Lerner, 1999; Kaplan and Schoar, 2005; Metrick and Yasuda, 2010). As a compensation for their intermediary role, GPs earn an annual management fee-usually ranging from 1.5 to 2 percent of the committed capital or assets under managementand a performance fee (also called "carried interest"), usually set at $20 \%$ of the fund's overall gross return. Instead, as the level of their direct investing expertise and 
capabilities is less than that of the GPs, LPs have limited or no control over the fund's portfolio companies and hence play a passive role as capital providers.

However, as depicted in fig. 10, LPs can provide a more blended direct investing setting by "coinvesting" alongside the private equity funds in a given deal preselected and proposed by the GPs. In such a case, the LPs play a more active role in deciding whether to invest and typically benefit from the lower fees charged by the GPs, who keep the control over the whole deal value chain, including the exiting decision. Compared to traditional delegated investing, coinvesting requires LPs to make quick decisions about investing in a specific asset, implying they must be able to conduct their own secondary due diligence process.

A still different business model is the "solo investing" one, where the institutional investors directly originate and invest in a given deal alone, without any kind of delegated scheme. Such a fully independent investment decision-making process, on the one hand, enables the LPs to save on the management and performance fees featured in the previous business models but, on the other hand, implies financial and nonfinancial capabilities in the selection phase as well as in the monitoring phase during the holding period: therefore, in order to build a truly skilled and legitimated internal investment team, there are significantly higher in-house costs to be sustained for LPs choosing a solo investing business model.

There are at least five different reasons behind this increased trend in institutional investors' direct private investments through solo or coinvesting business models (Fang et al., 2015).

First, to the subscribers of the funds' shares, direct investments do not entail the same investment costs that private equity funds charge, which are summarized by the previously described fee structure "2-and-20", in which "2" represents the annual management fee and "20" representing the carried interest. Consequently, the overall investment cost on an annual basis is estimated within the range 5 percent -7 percent, which obviously reduces the investors' net returns (Metrick and Yasuda, 2010).

Second, by direct investing, LPs enjoy the opportunity to obtain a wider control over their investment decisions, being able to select on their own ("cherry picking") the deals where to invest, whereas in the delegated investing setting, the LPs can only accept or reject the investment opportunities proposed by the GPs.

Additionally, direct investments give LPs the capability to better manage the time to market of their investment decisions. A consolidated research stream in the private equity literature shows that due to the existence of agency costs stemming from the delegation given to GPs, private equity investments are highly cyclical, making the performance achieved by the funds' subscribers more volatile and suboptimal (Gompers and Lerner, 2000; Kaplan and Schoar, 2005; Axelson et al., 2013). By adopting nondelegated investing business models, LPs might enjoy a higher degree of freedom in deciding when to invest or to suspend their investments, increasing their expected returns. 
Figure 10: Alternative business models in private equity investments A. Traditional fund investing

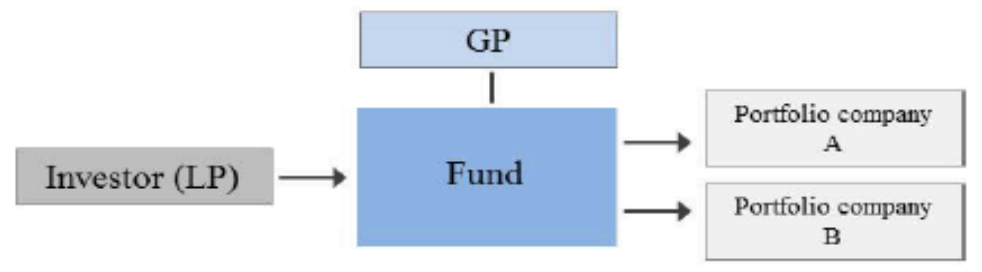

\section{B. Co-investing}

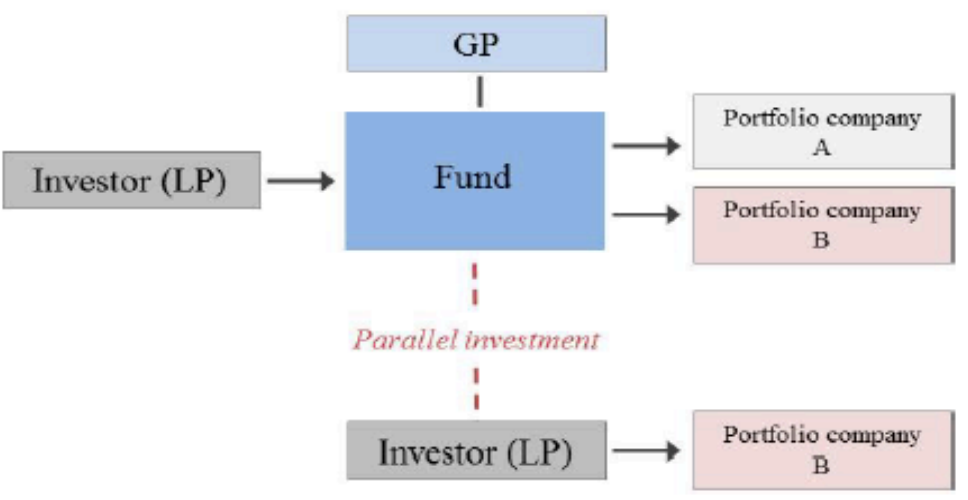

C. Solo investing

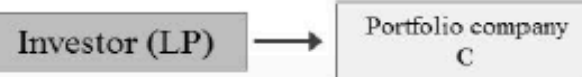

Fourth, direct investments also give the LPs a better ability to customize their risk exposures because the LPs do not have to rely on the GPs' decisions, such as those ones previously mentioned regarding the deal selection as well as the decisions on the size and timing of investments. Therefore, institutional investors benefit from an increased flexibility and customization of their investment policies, making their investment portfolios' risks more consistent with their expected risk-return profiles.

A final advantage of direct investing in private firms deals with a better alignment of the interests between the LPs and the GPs in a classic principal-agent problem (Lerner et al., 2007; Becker and Ivashina, 2015): in certain periods of the life of a closed-end fund, GPs might allocate a major share of their time to specific issues, such as trying to restructure a distressed portfolio company or executing an IPO for a performing company; the consequence for the GPS could be a type of distraction that might lead to a suboptimal investment process in hot markets at a time when it could be 
particularly appropriate to invest the fund's capital. The more active role played by the LPs in the coinvesting business model minimizes the principal-agent problem and guarantees a higher average asset quality over the whole fund's investment period.

\subsection{Outcomes and challenges for direct investing in private companies}

In addition to the many possible advantages, for institutional investors, direct investing also has challenges that have to be adequately faced.

In the case of solo investing, the biggest challenge deals with a lack of investment capability on the LPs side: therefore, in order to do solo deals, the LPs need to build those deal-level screening, due diligence, operational, monitoring and exiting capabilities that are traditionally part of the job of the GPs' managers. Such investment skills are costly ones, but on the other side, executing direct investments without those skills themselves may result in a worse asset quality when compared to that of private equity funds and, therefore, may also result in lower realized gross returns for the final investors (Fang et al., 2015).

There might be downsides also in the business model of coinvesting. First, coinvestments typically deal with larger-sized investments, allowing GPs to complement with further additional capital the private equity fund's available ticket size. On average, larger deals perform worse than the smaller-sized ones executed without the coinvesting business model (Lopez-de-Silanes et al., 2011). Second, as coinvesting partners, the GPs benefit from an information advantage over the LPs: the GPs typically manage the deal flow and screening process and offer investment opportunities to LPs with limited time windows to conduct their own due diligence and eventually accept to join the deals. This might also lead to an adverse selection problem, given that the GPs could invite LPs to join below average quality investment opportunities with the final effect of lower gross returns, which may not be offset by the lower operating costs in terms of management fees, carried interest fees as well as in the number and compensation of inside managers.

To investigate the existence of a trade-off between operating costs and investment quality across the abovementioned business models in private equity investments, Fang et al., 2015 compared the performance of a sample of 391 direct investments $(61 \%$ coinvestments and 39\% solo investments) made by a set of institutional investors between 1991 and 2011 against the performance of either public market indices ("PME ratios") or private equity and venture capital funds. As a major conclusion, the analysis suggested that direct investments, though performing better than do the tailored public market indices, do not significantly outperform relative to the performance indicated by the corresponding private equity fund benchmarks. For venture capital deals, the authors found that direct investments in startup companies underperform when compared to the performance indicated by the funds' benchmark across the whole sample period (fig. 11).

Fig. 11: Comparative analysis of direct investment performances: Public Market 


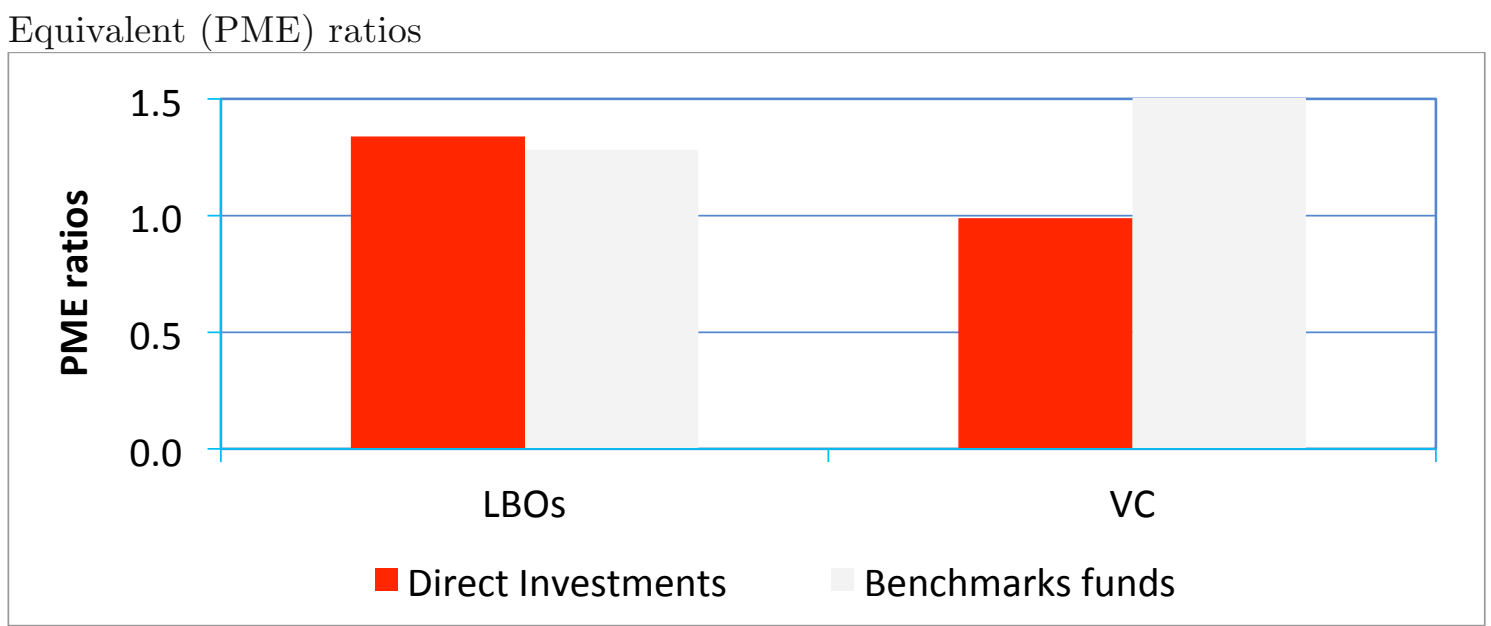

Source: Authors' elaboration from Fang et al., (2015).

Regarding the alternative business models in direct investments, coinvestments seem to underperform when comparing their performance to that of the investments of the corresponding fund with which they coinvest, with the performance gap widening in the more recent time window of the sample (the 2000s), thus confirming the presence of a possible adverse selection phenomenon (fig. 12).

Finally, solo investments slightly outperform fund investments, though the performance gap appears deteriorating over time. However, solo deals seem successful when the transaction involve companies that are already mature ("buy-out" deals), located close to the institutional investors ("local" deals) and that are not focused on complex production technologies ("plain vanilla" deals), all cases where information issues are less severe than those in the startup ecosystem.

Overall, it looks relatively difficult for institutional investors, without an adequate and expensive focused investment skillset, to capture the rents closed-end fund managers are able to achieve though their traditional fund-based business model. 
Fig. 12: Coinvestments relative performance (differences in performance between coinvestments and the corresponding fund)

\begin{tabular}{rrrlllll}
\hline & & \multicolumn{5}{c}{ Co-investment IRR - Fund IRR, (\%) } \\
\cline { 3 - 7 } Year & Obs. & \multicolumn{2}{c}{ Mean } & Std. dev. & \multicolumn{1}{c}{$25^{\text {th }} \%$} & Median & $75^{\text {th }} \%$ \\
\hline 1994 & 1 & 11.99 & -- & 11.99 & 11.99 & 11.99 \\
1997 & 2 & -52.93 & 81.85 & -110.80 & -52.93 & 4.95 \\
1999 & 1 & 2.06 & -- & 2.06 & 2.06 & 2.06 \\
2000 & 1 & 8.74 & -- & 8.74 & 8.74 & 8.74 \\
2001 & 4 & -4.15 & 40.97 & -34.67 & -2.60 & 26.37 \\
2002 & 3 & 47.72 & 40.14 & 1.40 & 69.30 & 72.46 \\
2003 & 3 & 18.14 & 19.04 & -2.40 & 21.60 & 35.21 \\
2004 & 4 & -2.85 & 90.81 & -79.25 & 8.90 & 73.55 \\
2005 & 10 & 2.79 & 29.92 & -15.99 & -9.24 & 18.55 \\
2006 & 18 & -10.51 & 30.03 & -17.95 & -6.37 & 2.30 \\
2007 & 33 & -16.08 & 33.46 & -20.34 & -6.32 & 0.70 \\
2008 & 9 & -25.54 & 31.92 & -23.80 & -11.06 & -6.80 \\
2010 & 8 & -1.27 & 30.03 & -13.21 & -8.60 & 15.75 \\
2011 & 6 & -13.22 & 8.27 & -16.90 & -13.60 & -9.30 \\
\hline Total & 103 & -8.98 & 36.70 & -17.95 & -7.3 & 2.8 \\
\hline
\end{tabular}

Source: Fang et al. (2015)

\subsection{Mutual funds as venture capitalists: preliminary evidence}

A further typology of institutional investors who are looking at the venture capital industry is constituted by the traditional open-end mutual funds.

A common framework in the finance setting seems to suggest that due to their openended nature and their obligation to meet all the redemption orders coming from the funds' shareholders, mutual funds should be unable to invest in illiquid securities (Chen et al., 2010; Chernenko and Sunderan, 2016; Goldstein et al., 2017). Moreover, by looking at the traditional business model of such funds, when compared to the venture capitalists' activism, the mutual funds' passive role as investors and their limited engagement with the firms in their portfolios are easily observable.

However, in the last few years, a rising a trend has been emerging, as mutual funds have directly invested in private firms (Kwon et al., 2017; Chernenko et al., 2017), with a special focus on those firms with estimated valuations of above a billion dollars, also known as "unicorns"), providing scholars the opportunity to investigate whether and how passive institutional investors contribute to the performance of such private investments.

Chernenko et al. (2017), by focusing on the contractual provisions associated with mutual funds' direct investments in unicorns, tried to identify the determinants of mutual fund investments and the extent of their involvement in the monitoring and 
governance of these companies. The authors, building a sample of 153 private firms undergoing investment rounds by open-end mutual funds in the 2012-2016 time period, found first of all that it was a relatively reasonable expectation that larger-sized funds and funds with more stable funding are more likely to invest in unicorns. More interesting, focusing on traditional corporate governance provisions (cash flow rights, voting and control rights, board representation mechanisms), they found mutual funds do provide much less governance services than traditional closed-end venture capital funds do. At the same time, the authors found that mutual funds' investments are associated with significantly stronger redemption rights and less strict formal procedures to trigger the redemption itself (fig 13).

Fig. 13: Contractual provisions in rounds with or without mutual funds This figure reports the conditional distribution of financing round with and without mutual fund participation over participation rights, redemption rights, and the number of separate class directors.
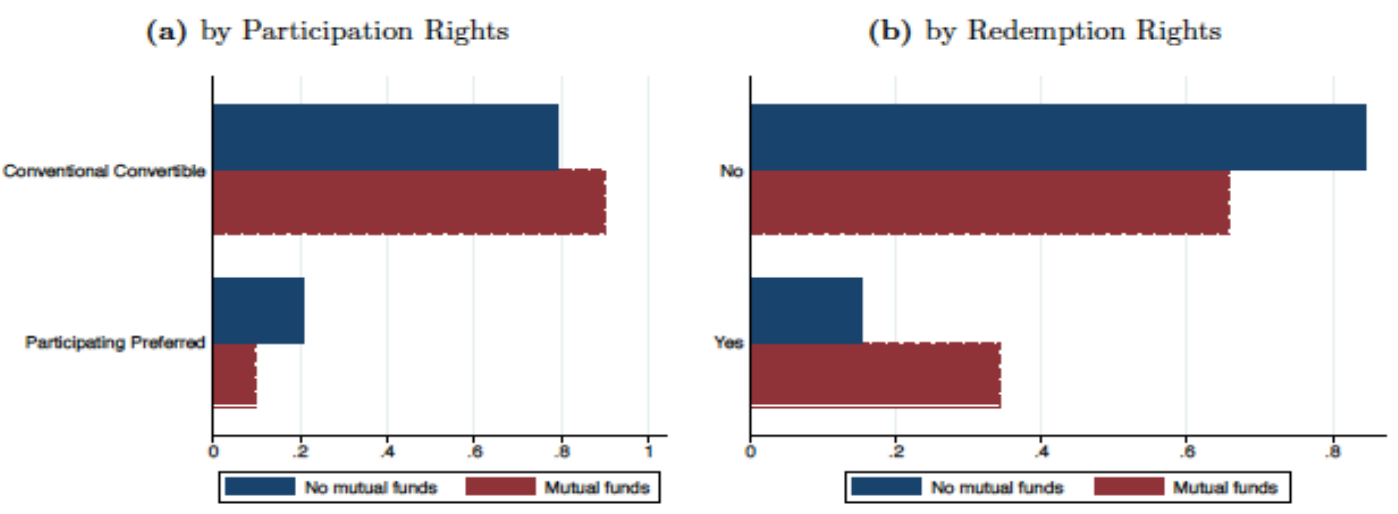

(c) by Number of Class Directors

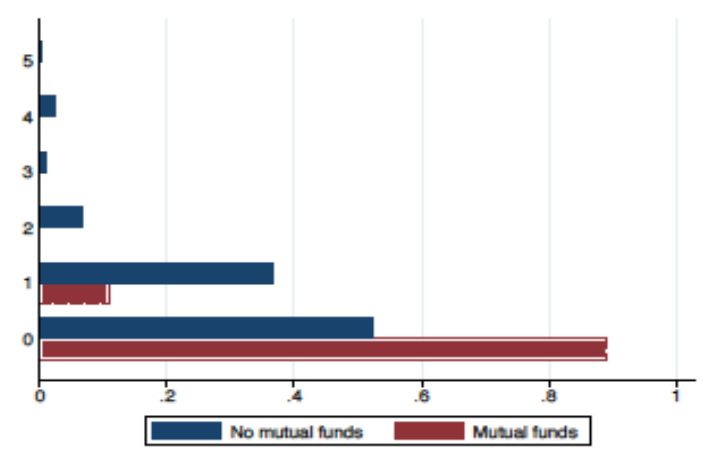

Source: Chernenko et al., (2017)

Overall, the results of the empirical analysis suggest that once again traditional institutional investors' managers are unlikely to have the investment skills and capabilities required to monitor unlisted small companies or even to contribute to their strategy formulation and operations management. However, the need to hedge 
illiquidity risk pushes portfolio managers to actively manage their assets, making them better able to redeem their stocks in the portfolio companies when facing redemption pressures from their own shareholders, leaving as an open issue, with respect to new ventures, the identification of an adequate "fundraising mix" capable of leveraging on the heterogeneous contribution different financial investors can bring to entrepreneurs.

\section{Conclusions}

In the last few decades, the emergence of many different incumbents reshaped and dramatically widened the startup ecosystem, once the exclusive preserve of venture capitalists, particularly in the well-known investment business model of the closed-end funds.

Startup incubators and accelerators are becoming more numerous and are increasingly offering equity capital alongside their mentoring and education services. Business angels are progressively deploying more of their wealth in startup investments and have begun structuring themselves in angel investment organizations. Crowdfunding platforms are intercepting massive capital flows from accredited and unaccredited investors across countries all around the world and, furthermore, more and more institutional investors are abandoning the traditional venture capital and private equity setting in favor of direct investments through solo and coinvesting.

Each one of these actors within the entrepreneurial finance ecosystem have surely widened the funding options available to new ventures, highly increasing the capability of the financial system to boost innovation and entrepreneurship. However, what about the market opportunities for venture capital? For venture capitalists, is it reasonable to assume that the rising investors are threatening their growth or making their role thinner in this risky and opaque segment of the capital markets?

In this paper, together with the major strengths, we have presented the major challenges related to the development of the emerging actors mentioned above.

The average angel investor appears to lack investment expertise and might not be prepared to invest in truly radical high growth projects. In addition, firms seem to "selfcensor" when they apply to angel groups, consistent with the perceived higher risk aversion of BAs as well as their having less background than venture capitalists have in assessing very early-stage investments.

Crowdfunding is dominated by high information asymmetry, leading to selection issues when one considers that project backers are usually less sophisticated and inexperienced investors. Additionally, the crowd may not have the adequate background and cognitive orientation required to understand and select radically innovative projects. After the deal, another challenge is that many investors do not have the skills and capabilities to offer a nonmonetary contribution aimed at supporting the value creation path of the target companies. Furthermore, in many countries, the legal response given by regulatory authorities to manage the fraudulent behavior that may affect crowdfunding has been very slow. Even if crowdfunding platforms are trying to protect project 
backers from risks, information asymmetry is still an open issue preventing many possible investors from gaining access to this segment of capital markets or, alternatively, due to plagiarism risk, preventing many entrepreneurs from sharing their ideas on the web platforms

With direct-investment by institutional investors, the different approaches to private equity investing present a puzzling tradeoff between cost and investment quality. Fund investing is rather expensive because of the management and performance fees charged by the closed-end funds, but the average cheaper deal invested in by funds may be of a higher quality; direct investing may not cost as much, but the typical transaction may be of worse quality. Reinforcing this type of equilibrium is the fact that the staff of the LPs typically receives lower compensation than investment professionals in private equity and venture capital funds do, reflecting the frequent association of institutional investors with government or nonprofit firms.

Although they are widespread, those alternative emerging actors within the entrepreneurial finance ecosystem do not seem to be able (yet) to make the VC system wholly obsolete. It's still a matter of human capital, adequate investment skills and capabilities to deal with screening, negotiating and monitoring these opaque and risky assets, which are fundamental for the growth of the economy.

We leave to future research the issue of investigating the conditions under which all the major different categories and business models of alternative investors in unlisted companies will achieve legitimation and economic justification. Furthermore, another promising research stream will be focused on the analysis of the many different and alternative funding trajectories arising from the financing choices of new ventures, selecting specific investors over other investors, or the mixing in different ways of the available opportunities offered by the startup ecosystem. 


\section{References}

ACA - Angel Capital Association (2016), Angel Funders Report. Available at: https://www.angelcapitalassociation.org/angel-funders-report.

Admati, A. and Pfleiderer, P. (1994), Robust Financial Contracting and the Role of Venture Capitalists. Journal of Finance, Vol. 49, No. 2, 371-402.

Amit, R., Brander, J. and Zott, C. (1998), Why do venture capital firms exist? Theory and Canadian evidence. Journal of Business Venturing, Vol. 13, No. 6, 441-466.

Ang, J.S. (1992), On the Theory of Finance for Privately Held Firms. Journal of Small Business Finance, Vol. 1, No. 3, 185-203.

Armour, J. and Enriques, L. (2018a), Individual Investors' Access to Crowdinvesting: Two Regulatory Models. In Cumming, D. and Hornuf, L. (eds), The Economics of Crowdfunding, London, UK: Palgrave Macmillan, 2018, 255-279.

Armour, J. and Enriques, L. (2018b), The Promise and Perils of Crowdfunding: Between Corporate Finance and Consumer Contracts. Modern Law Review, Vol. 81, No. 1, 51-84.

Avdeitchikova, S. and Landström, H. (2016), The economic significance of business angels: toward comparable indicators, In: Landström, H. and Mason, C. (eds.), Handbook of Research on Business Angels, Cheltenham, UK: Edward Elgar Publishing, 2016, pp. 53-75.

Axelson, U., Jenkinson, T., Strömberg, P. and Weisbach M. S. (2013), Borrow Cheap, Buy High? The Determinants of Leverage and Pricing in Buyouts. Journal of Finance, Vol. 68, No. 6, 2223-2267.

Becker, B. and Ivashina, V. (2015), Reaching for Yield in the Bond Market. Journal of Finance, Vol. 70, No. 5, 1863-1902.

Bellavitis, C., Filatotchev, I., Kamuriwo, S. D. and Vanacker, T. (2017), Entrepreneurial finance: new frontiers of research and practice. Venture Capital: An International Journal of Entrepreneurial Finance, Vol. 19, No. 1-2, 1-16.

Belleflamme, P., Lambert, T. (2014), Crowdfunding: Some Empirical Findings and Microeconomic Underpinnings. Available at SSRN: htps://ssrn.com/abstract $=2437786$

Belleflamme, P., Lambert, T. and Schwienbacher, A. (2013), Individual crowdfunding practices. Venture Capital: An International Journal of Entrepreneurial Finance, Vol. 15, No. 4, 313-333.

Belleflamme, P., Lambert, T. and Schwienbacher, A. (2014), Crowdfunding: Tapping the right crowd. Journal of Business Venturing, Vol. 29, No. 5, 585-609.

Belleflamme, P., Omrani, N. and Peitz, M. (2015), The economics of crowdfunding platforms. Information Economics and Policy. Vol. 33, No. C, 11-28. 
Bergemann, D. and Hege, U. (1998), Venture capital financing, moral hazard, and learning. Journal of Banking \& Finance, Vol. 22, No. 6-8, 703-735.

Berger, A. and Udell, G. (1998), The economics of small business finance: The roles of private equity and debt markets in the financial growth cycle. Journal of Banking \& Finance, Vol. 22, No. 6-8, 613-673.

Bessière, V., Stephany, E. and Wirtz, P. (2018), Crowdfunding, Business Angels, and Venture Capital: New Funding Trajectories for Start-Ups? Available at SSRN: https://ssrn.com/abstract $=3137095$.

Black, B. and Gilson, R. J. (1998),Venture capital and the structure of capital markets: banks versus stock markets. Journal of Financial Economics, Vol. 47, No. 3, 243-277.

Block, J., Hornuf, L. and Moritz, A. (2018), Which Updates During an Equity Crowdfunding Campaign Increase Crowd Participation? Small Business Economics, Vol. 50, No. 1, 3-27.

Bonini, S. and Capizzi, V. (2017), The effects of private equity investors on the governance of companies. In Gabrielsson, J. (ed.), Handbook of Research on Entrepreneurship and Corporate Governance, Camberley, UK: Edward Elgar Publishing, 2017, 164-200.

Bonini, S., Capizzi, V. and Zocchi, P. (2017), The performance of angel-backed companies. Available at SSRN: https://ssrn.com/abstract $=3039307$.

Bonini, S., Capizzi, V., Valletta, M. and Zocchi, P. (2018), Angel network affiliation and business angels' investment practices. Journal of Corporate Finance, Vol. 50, No. 6, 592-608.

Bradford, C. S. (2012), Crowdfunding and the Federal Securities Laws. Columbia Business Law Review, Vol. 1, No. 1, 5-150.

Bradford, C. S. (2018), The Regulation of Crowdfunding in the United States. In Cumming, D. and Hornuf, L. (eds), The Economics of Crowdfunding, London, UK: Palgrave Macmillan, 2018, 185-217.

Brush, C. G., Edelman, L. F. and Manolova, T. S. (2012), Ready for funding? Entrepreneurial ventures and the pursuit of angel financing. Venture Capital: An International Journal of Entrepreneurial Finance, Vol. 14, No. 2-3, 111-129.

Bruton, G. D., Fried, V. H. and Manigart, S. (2005), Institutional Influences on the Worldwide Expansion of Venture Capital. Entrepreneurship Theory and Practice, Vol. 29, No. 6, 737-760.

Bruton, G., Chahine, S. and Filatotchev, I. (2009), Founders, Private Equity Investors, and Underpricing in Entrepreneurial IPOs. Entrepreneurship Theory and Practice, Vol. 33, No. 4, 909-928. 
Bruton, G., Khavul, S., Siegel, D., and Wright, M. (2015), New Financial Alternatives in Seeding Entrepreneurship: Microfinance, Crowdfunding, and Peer-to-Peer Innovations. Entrepreneurship Theory and Practice, Vol. 39, No. 1, 9-26.

Burns, P. (2001), Entrepreneurship and small business. Hampshire, UK: Palgrave Macmillan, 2001, 1-418.

Busenitz, L. W., West, G. P., Shepherd, D., Nelson, T., Chandler, G. N. and Zacharakis, A. (2003). Entrepreneurship Research in Emergence: Past Trends and Future Directions. Journal of Management, Vol. 29, No. 3, 285-308.

Capizzi, V. (2015), The returns of business angel investments and their major determinants. Venture Capital: An International Journal of Entrepreneurial Finance, Vol. 17, No. 4, 271-298.

Capizzi, V. and Carluccio, E. (2016), Competitive Frontiers in Equity Crowdfunding: The Role of Venture Capitalists and Business Angels in the Early-Stage Financing Industry. In Bottiglia, R. and Pichler, F. (eds.), Crowdfunding for SMEs: A European Perspective, London, UK: Palgrave Macmillan, 117-157.

Carey, M. S., Prowse, S. D., Rea, J. and Udell, G. F. (1993), The economics of the private placement market. Staff Studies, No. 166, Board of Governors of the Federal Reserve System (U.S.), 1-118.

Chan, R. C. S. and Parhankangas, A. (2017), Crowdfunding Innovative Ideas: How Incremental and Radical Innovativeness Influence Funding Outcomes. Entrepreneurship Theory and Practice, Vol. 41, No. 2, 237-263.

Chan, Y. S., (1983), On the positive role of financial intermediation in allocation of venture capital in market with imperfect information. Journal of Finance, Vol. 38, No. 5, 1543-1568.

Chemmanur, T. J. and Chen (2014), Venture capitalists versus angels: The dynamics of private firm financing contracts. Review of Corporate Finance Studies, Vol. 3, No. $1-2,39-86$.

Chemmanur, T. J., Krishnan, K. and Nandy, D. K. (2011), How Does Venture Capital Financing Improve Efficiency in Private Firms? A Look Beneath the Surface. Review of Financial Studies, Vol. 24, No. 12, 4037-4090.

Chen, Q., Goldstein, I. and Jiang, W. (2010), Payoff Complementarities and Financial Fragility: Evidence from Mutual Fund Outflows. Journal of Financial Economics, Vol. 97, No. 2, 239-262.

Chernenko, S. and Sunderan, A. (2016), Liquidity Transformation in Asset Management: Evidence from the Cash Holdings of Mutual Funds. NBER Working Paper, No. 22391, July 2016, 1-62.

Chernenko, S., Lerner, J. and Zeng, Y. (2017), Mutual Funds As Venture Capitalists? Evidence from Unicorns. Available at SSRN: https://ssrn.com/abstract=2897254. 
Chung, J. W., Sensoy, B. A., Stern, L. and Weisbach, M. S. (2012) Pay for Performance from Future Fund Flows: The Case of Private Equity. Review of Financial Studies, Vol. 25, No. 11, 3259-3304.

Colombo, M. G. and Grilli, L. (2010), On growth drivers of high-tech start-ups: exploring the role of founders' human capital and venture capital. Journal of Business Venturing, Vol. 25, No. 6, 610-626.

Colombo, M. G., Franzoni, C. and Rossi-Lamastra, C. (2015), Internal social capital and the attraction of early contributions in crowdfunding. Entrepreneurship Theory and Practice, Vol. 39, No. 1, 75-100.

Cordova, A., Dolci, J. and Gianfrate, G., (2015), The Determinants of Crowdfunding Success: Evidence from Technology Projects. Procedia - Social and Behavioural Sciences, Vol. 181, 115-124.

Cornelli, F. and Yosha, O. (2003), Stage Financing and the Role of Convertible Securities. Review of Economic Studies, Vol. 70, No. 1, 1-32.

Croce, A., Martí, J. and Murtinu, S. (2013), The impact of venture capital on the productivity growth of European entrepreneurial firms: 'Screening' or 'value added' effect? Journal of Business Venturing, Vol. 28, No.4, 489-510.

Cumming, D. (2006), Adverse selection and capital structure: Evidence from venture capital. Entrepreneurship Theory and Practice, Vol. 30, No. 2, 155-183.

Cumming, D. (2008), Contracts and exits in venture capital finance. Review of Financial Studies, Vol. 21, No. 5, 1947-1982.

Cumming, D. (2012) (ed.), The Oxford Handbook of Venture Capital, Oxford University Press, New York, US: Oxford University Press, 1-995.

Cumming, D., and Johan, S. (2013), Venture Capital and Private Equity Contracting: An International Perspective, 2nd Edition. Amsterdam, The Netherlands: Elsevier Science Academic Press, 1-727.

Cumming, D. and Zhang, Y. (2016), Alternative investments in emerging markets: A review and new trends. Emerging Markets Review, Vol. 29, No. 1, 1-29.

Cumming, D. and Vismara, S. (2017), De-segmenting Research in Entrepreneurial Finance. Venture Capital: An International Journal of Entrepreneurial Finance, Vol. 19, No. 1-2, 17-27.

Cumming, D. and Hornuf, L. (eds.) (2018), The Economics of Crowdfunding, London, UK: Palgrave Macmillan, 1-279.

DeAngelo, H. and Masulis, R. (1980), Capital structure under corporate and personal taxation. Journal of Financial Economics, Vol. 8, No. 1, 3-29.

De Buysere, K., Gajda, O., Kleverlaan, R. and Marom, D. (2012), A Framework for European Crowdfunding. Available at: http://evpa.eu.com/wpcontent/uploads/2010/11/European_Crowdfunding_Frame 
work_Oct_2012.pdf.

Djankov, S., La Porta, R., Lopez-de-Silanez, F. and Shleifer, A. (2002), The Regulation of Entry. Quarterly Journal of Economics, Vol. 117, No. 1, 1-37.

Djankov, S., La Porta, R., Lopez-de-Silanez, F. and Shleifer, A. (2008), The Law and Economics of Self-Dealing. Journal of Financial Economics, Vol. 88, No. 3, 430465 .

Dushnitsky, G., Guerini, M., Piva, E. and Rossi-Lamastra, C. (2016), Crowdfunding in Europe: Determinants of Platform Creation across Countries. California Management Review, Vol. 58, No. 2, 44-71.

EBAN (2017), Activity Report 2016. Available at: www.eban.org.

Edelman, L. F., Manolova, T. S. and Brush, C. G. (2017), Angel Investing: A Literature Review. Foundations and Trends ${ }^{\circledR}$ in Entrepreneurship, Vol. 13, No. 4$5,265-439$.

Erenburg, G., Smith, J. K., and Smith, R. (2016), Which institutional investors matter for firm survival and performance? The North American Journal of Economics and Finance, Vol. 17, No. 3, 348-373.

EY (2017), 2017 Global PE Watch. Available at: https://www.ey.com/Publication/vwLUAssets/ey-2017-global-pe-watch/\$FILE/ey2017-global-pe-watch.pdf.

Fama, E. and French, K. (2002), Testing Trade-Off and Pecking Order predictions about dividends and debt. Review of Financial Studies, Vol. 15, No. 1, 1-33.

Fang, L H., Ivashina, V. and Lerner, J. (2015), The Disintermediation of Financial Markets: Direct Investing in Private Equity. Journal of Financial Economics, Vol. 116, No. 1, 160-178.

Filatotchev, I., Wright, M. and Arberk, M. (2006), Venture Capitalists, Syndication and Governance in Initial Public Offerings. Small Business Economics, Vol. 26, No. 4, 337-350.

Fraser, S., Bhaumik, S. K. and Wright, M. (2015), What do we know about entrepreneurial finance and its relationship with growth? International Small Business Journal, Vol. 33, No. 1, 70-88

Fried, V. H. and Hisrich, R. D. (1988), Venture capital research: past, present, and future. Entrepreneurship Theory and Practice, Vol. 13, No. 1, 15-28.

Gerber, E. M., Hui, J. S. and Kuo, P. Y. (2012), Crowdfunding: Why people are motivated to post and fund projects on crowdfunding platforms. Proceedings of the International Workshop on Design, Influence, and Social Technologies: Techniques, Impacts and Ethics, Vol. 2, 1-10.

Gerber, E. M. and Hui, J. S. (2013), Crowdfunding: Motivations and deterrents for participation. ACM Transactions on Computer-Human Interaction, Vol. 20, No. 6., 1-34. 
Giot, P. and Schwienbacher, A. (2007), IPOs, trade sales and liquidations: Modelling venture capital exits using survival analysis. Journal of Banking \& Finance, Vol. 31, No. 2, 679-702.

Giudici, G., (2016), Equity crowdfunding of an entrepreneurial activity. In Audretsch, D., Lehmann, E., Meoli, M. and Vismara, S. (eds.), University Evolution, Entrepreneurial Activity and Regional Competitiveness. New York, NY: Springer, 415-425.

Goldfarb, B., Hoberg, G., Kisch, D., and Triantis, A. (2013), Are Angels Different? An Analysis of Early Venture Financing. Robert H. Smith School of Business Research Paper Series, No. 06-072, November 2013. Available at SSRN: https://ssrn.com/abstract $=1024186$.

Goldstein, I., Jiang, H. and Ng, D. (2017), Investor Flows and Fragility in Corporate Bond Funds. Journal of Financial Economics, Vol. 126, No. 3, 592-613.

Gompers, P. (1995), Optimal investment, monitoring, and the staging of venture capital. Journal of Finance, Vol. 50, No. 5, 1461-1489.

Gompers, P. and Lerner, J. (1999), An analysis of compensation in the U.S. venture capital partnership. Journal of Financial Economics, Vol. 51, No. 1, 3-44.

Gompers, P. and Lerner, J. (2004), The Venture Capital Cycle. Cambridge, MA: The MIT Press, 1-531.

Gompers, P.A. and Lerner, J. (2001), The Venture Capital Revolution. Journal of Economics Perspectives, Vol. 15, No. 2, 145-168.

Gregson, G., Mann, S. and Harrison, R. T. (2013), Business angel syndication and the evolution of risk capital in a small market economy: Evidence from Scotland. Managerial and Decision Economics, Vol. 34, No. 2, 95-107.

Griffin, Z. J. (2012), Crowdfunding: Fleecing the American masses. Journal of Law, Technology 85 the Internet, Vol. 4, No. 2, 375-410.

Hainz, C. (2018), Fraudulent Behavior by Entrepreneurs and Borrowers. In Cumming, D. and Hornuf, L. (eds.), The Economics of Crowdfunding, London, UK: Palgrave Macmillan, 79-99.

Hall, B. H. and Lerner, J. (2010), The Financing of R\&D and Innovation. In Hall, B. H. and Rosenberg, N. (eds.), Handbook of the Economics of Innovation. Vol. 2, Amsterdam, The Netherlands: Elsevier Science Academic Press, 609-639.

Harrison, R. T. (2013), Crowdfunding and the revitalisation of the early stage risk capital market: catalyst or chimera? Venture Capital: An International Journal of Entrepreneurial Finance, Vol. 15, No. 4, 283-287.

Harrison, R. T. (ed.) (2015), Crowdfunding and Entrepreneurial Finance. Abingdon, UK: Routledge, 1-152.

Harrison, R. T. and Mason, C. M. (1992), International perspectives on the supply of 
informal venture capital. Journal of Business Venturing, Vol. 7, No. 6, 459-475.

Harrison, R. T. and Mason, C. M. (2017), Backing the horse or the jockey? Due diligence, agency costs, information and the evaluation of risk by business angel investors. International Review of Entrepreneurship, Vol. 15, No. 3, 269-290.

Hellmann, T. (2006), IPOs, acquisitions, and the use of convertible securities in venture capital. Journal of Financial Economics, Vol. 81, No. 3, 649-679.

Hellmann, T. and Puri, M. (2000), The interaction between product market and financing strategy: The role of venture capital. Review of Financial Studies, Vol. 13, No. 4, 959-984.

Hellman, T. and Thiele, V. (2015), Friends or foes? The interrelationship between angel and venture capital markets. Journal of Financial Economics, Vol. 115, No. 3, 639653.

Hellman, T., Schure, P. and Vo, D. (2017), Angel and Venture Capitalists: Substitutes or Complements? Saïd Business School WP 2015-2. Available at SSRN: https://ssrn.com/abstract $=2602739$.

Hervé, F., E. Manthe, A. Sanajust, and A. Schwienbacher. 2016. "Investor Motivations in Investment-based Crowdfunding". Available at SSRN: https://ssrn.com/abstract $=2746398$.

Hoffman, D. L. and Radojevich-Kelley, N. (2012), Analysis of Accelerator Companies: An Exploratory Case Study of Their Programs, Processes, and Early Results. Small Business Institute ${ }^{\circledR}$ Journal, Vol. 8, No. 2, 54-70.

Hornuf, L. and Schmitt, M. (2016), Success and failure in equity crowdfunding. CESifo DICE Report, Vol. 14, No. 2, 16-22.

Hornuf, L. and Schwienbacher, A. (2016), Market mechanisms and funding dynamics in equity crowdfunding. Journal of Corporate Finance, Vol. 50, No. 6, 556-574.

Ibrahim, D. M. (2008), The (not so) puzzling behavior of angel investors. Vanderbilt Law Review, Vol. 61, No. 5, 1405-1452.

InvestEurope (2018), European Private Equity Report 2017. Available at: https://www.investeurope.eu/media/742312/investeurope_comres_globalinvestment-decision-makers-survey-2018.pdf

Isenberg, D. (2010), How to start an entrepreneurial revolution. Harvard Business Review, Vol. 88, No. 6, 40-50.

Iyer, R., Khwaja, A. I., Luttmer, E. F. P. and Shue, K. (2016), Screening Peers Softly: Inferring the Quality of Small Borrowers. Management Science, Vol. 62, No. 6, 1554-1577.

Jensen, M. (1986), Agency Costs of Free Cash Flow, Corporate Finance, and Takeover. American Economic Review, Vol. 76, No. 2, 323-329.

Jensen, M. C. and Meckling, W.H. (1976), Theory of the firm: Managerial behavior, 
agency costs and ownership structure. Journal of Financial Economics, Vol. 3, No. 4, 305-360.

Kaplan, S. and Stromberg, P. (2003), Financial contracting theory meets the real world: Evidence from venture capital contracts. Review of Economic Studies, Vol. 7, No. 2, 281-315.

Kaplan, S. and Schoar, A. (2005), Private Equity Performance: Returns, Persistence, and Capital Flows. Journal of Finance, Vol. 60, No. 4, 1791-1823.

Kaplan, S. and Lerner, J. (2017), Venture Capital Data: Opportunities and Challenges. in Haltiwanger, J., Hurst, E., Miranda, J. and Schoar, A. (eds.), Measuring Entrepreneurial Businesses: Current Knowledge and Challenges, NBER Books, Chicago, US: University of Chicago Press, 413-431.

Kerr, William R., Josh Lerner, and Antoinette Schoar (2014), The Consequences of Entrepreneurial Finance: A Regression Discontinuity Analysis. Review of Financial Studies, Vol. 27, No. 1, 20-55.

Kerr, William R. and Nanda, R. (2014), Financing Innovation. Annual Review of Financial Economics, Vol. 7, No. 1, 445-462.

Kirby, E. and Worner, S. (2014), Crowd-funding: An Infant Industry Growing Fast. IOSCO Staff Working Paper, SWP3/2014, February, 1-63.

Kleemann, F., Voss, G. and Rieder, K. M. (2008), Un(der)Paid Innovators: The Commercial Utilization of Consumer Work through Crowdsourcing. Science, technology 63 innovation studies, Vol. 4, No. 1, 5-26.

Klöhn, L., Hornuf, L. and Schilling, T. (2016), Financial Contracting in Crowdinvesting: Lessons from the German Market. Available at SSRN: https://ssrn.com/abstract $=2839041$.

Kraemer-Eis, H., Botsari, A., and Prencipe, D. (2016), The European venture capital landscape: an EIF perspective. EIF Research \& Market Analysis, working paper, No. 2016/34, 1-64.

Kraemer-Eis, H., Signore, S., Gvetadze, S., Lang, F. and Torfs, W. (2017), European Small Business Finance Outlook. EIF Research \& Market Analysis, working paper, No. 2017/46, 1-134.

Kuppuswammy, V. and Roth, K. (2016), Research on the Current State of Crowdfunding: The Effect of Crowdfunding Performance and Outside Capital. U.S. Small Business Administration, Office of Advocacy, No. SBAHQ-15-M-0114, May 2016, 1-36.

Kwon, S., Lowry, M. B. and Qian, Y. (2017), Mutual Fund Investments in Private Firms. Available at SSRN: https://ssrn.com/abstract=2941203.

Lahti T. and Keinonen, H. (2016), Business angel networks: a review and assessment of their value to entrepreneurship. In Landström, H. and Mason (eds.), Handbook of 
Research on Business Angels. Cheltenham, UK: Edward Elgar Publishing, 354-380.

Lambert, T. and Schwienbacher, A. (2010), An Empirical Analysis of Crowdfunding. Available at SSRN: http://ssrn.com/abstract=1578175.

Lambert, T., Ralcheva, A. and Roosenboom, P., (2018), The Crowd-Entrepreneur Relationship in Start-Up Financing. In Cumming, D. and Hornuf, L. (eds.), The Economics of Crowdfunding, London, UK: Palgrave Macmillan, 57-78.

Landström, H. (1993), Informal risk capital in Sweden and some international comparisons. Journal of Business Venturing, Vol. 8, No. 6, 525-540.

Landström, H. and Mason, C. M. (2016), Business angels as a research field. In Landström, H. and Mason, C. M. (eds.), Handbook of Research on Business Angels. Cheltenham, UK: Edward Elgar Publishing, 1-24.

La Porta, R., Lopez-de-Silanez, F. and Shleifer, A. (1998), Law and finance. Journal of Political Economy, Vol. 106, No. 6, 1113-1155.

La Porta, R., Lopez-de-Silanes, F., Shleifer, A. and Vishny, R. W. (2000), Investor Protection and Corporate Governance. Journal of Financial Economics, Vol. 58, No. 1-2, 3-27.

La Porta, R., Lopez-de-Silanez, F. and Shleifer, A. (2013), Law and finance after a decade of research. In Constantinides, G., Harris, M. and Stulz, R. M. (eds.), Handbook of the Economics of Finance. Vol. 2. Amsterdam, The Netherlands: Elsevier Science Academic Press, chapter 6, 425-491.

Leboeuf, G. and Schwienbacher, A. (2018), Crowdfunding as a New Financing Tool. In Cumming, D. and Hornuf, L. (eds.), The Economics of Crowdfunding, London, UK: Palgrave Macmillan, 11-28.

Lerner, J. (1994), The syndication of venture capital investments. Financial Management, Vol. 23, No. 3, 16-27.

Lerner, J. (1995), Venture capitalists and the oversight of private firms. Journal of Finance, Vol. 50, No.1, 301-318.

Lerner, J., Schoar, A. and Wongsunwai, W. (2007), Smart institutions, foolish choices: The limited partner performance puzzle. Journal of Finance, Vol. 62, No. 2, 731764 .

Lerner, J., Schoar, A., Sokolinski, S. and Wilson, K. (2016) The Globalization of Angel Investments: Evidence Across Countries, HBS Working Paper, No. 16-072, 1-53.

Ley, A. and Weaven, S. (2011), Exploring agency dynamics of crowdfunding in start-up capital financing. Academy of Entrepreneurship Journal, Vol. 17, No. 1, 85-110.

Li, E. and Martin, J. S. (2016), Capital formation and financial intermediation: The role of entrepreneur reputation formation. Journal of Corporate Finance. In Press. Available online 21 April 2016, https://doi.org/10.1016/j.jcorpfin.2016.04.002.

Liang, Z. (2015), Crowdfunding in China: Potentials, Challenges, Risks and Solutions. 
Crowdfund Insider. October $6^{\text {th }}$, 2015. Available at: https://www.crowdfundinsider.com/2015/10/75384-crowdfunding-in-chinapotentials-challenges-risks-and-solutions.

Lin, L. (2017), Managing the risks of equity crowdfunding: lessons from China. Journal of Corporate Law Studies, Vol. 17, No. 2, 327-366.

Lopez-de-Silanes, F., Phalippou, L. and Gottschalg, O. (2011), Giants at the gate: On the cross-section of private equity investment returns. Tinbergen Institute Discussion Paper, No. 11-035/2/DSF12, 1-67.

Manigart, S., de Waele, K., Wright, M., Robbie, K., P. Desbrieres, P., Sapienza, H. J. and A. Beekman, A. (2002), Determinants of required return in venture capital investments: a five-country study. Journal of Business Venturing, Vol. 17, No. 4, $291-312$.

Manigart, S., Lockett, A., Meuleman, M., Wright, M., Landström, H., Bruining, H., Desbrières, P. and Hommel, U. (2006), Venture Capitalists' Decision to Syndicate. Entrepreneurship Theory and Practice, Vol. 30, No. 2, 131-153.

Mason, C. (2016), Researching business angels: definitional and data challenges. In Landström, H. and Mason (eds.), Handbook of Research on Business Angels. Cheltenham, UK: Edward Elgar Publishing, 25-52.

Mason, C. M. (2006), Informal sources of venture finance. In Parker, S. C. (ed.), The Life Cycle of Entrepreneurial Ventures. New York, NY: Springer, 259-299.

Mason, C. M. (2008), The Real Venture Capitalists: A Review of Research on Business Angels. Working Paper WP08-06, Hunter Center for Entrepreneurship, University of Strathclyde, September 2008, 1-55.

Mason, C. M. and Harrison, R. T. (2000), The size of the informal venture capital market in the United Kingdom. Small Business Economics, Vol. 15, No. 2, 137148.

Mason, C. M. and Harrison, R. T. (2004), Does investing in technology-based firms involve higher risk? An exploratory study of the performance of technology and non-technology investments by business angels. Venture Capital: An International Journal of Entrepreneurial Finance, Vol. 6, No. 4, 313-332.

Mason C. M. and Harrison R. T. (2008), Measuring business angel investment activity in the United Kingdom: A review of potential data sources, Venture Capital: An International Journal of Entrepreneurial Finance, Vol. 10, No. 4, 309-330.

Mason, C. M., Botelho, T., and Harrison, R. T. (2013), The Transformation of the Business Angel Market: Evidence from Scotland. Available at: http://dx.doi.org/10.2139/ssrn.2306653.

Mason, C. M., Botelho, T., and Harrison, R. T. (2016), The Transformation of the Business Angel Market: empirical evidence and research implications. Venture Capital: An International Journal of Entrepreneurial Finance, Vol. 19, No. 4, 321- 
344.

Mason, C. M., Botelho, T., and Harrison, R. T. (2018), The Changing Nature of Angel Investing: some research implications. Venture Capital: An International Journal of Entrepreneurial Finance, forthcoming.

Massolution (2017), The Crowdfunding Industry Report, 2017. Available at: www.crowdsourcing.org.

Metrick, A. and Yasuda, A. (2010), The economics of private equity funds. Review of Financial Studies, Vol. 23, No. 6, 2302-2341.

2303-2341. Mitchell, L. (2010). Beyond licensing and incubators: Next-Generation approaches to entrepreneurial growth at universities. Ewing Marion Kauffman Foundation, Report. Available at: https://www.scribd.com/document/13220935/Beyond-Licensing-and-Incubators.

Modigliani, F. and Miller, M.H. (1958), The Cost of Capital, Corporation Finance, and the Theory of Investment. American Economic Review, Vol. 48, No. 3, 261-297.

Modigliani, F. and Miller, M.H. (1963), Corporate Income Taxes and the Cost of Capital: A Correction. American Economic Review, Vol. 53, No. 3, 433-443.

Mollick, E. (2013), Swept Away by the Crowd? Crowdfunding, Venture Capital, and the Selection of Entrepreneurs. Available at SSRN: https://ssrn.com/abstract $=2239204$.

Mollick, E. (2014), The dynamics of crowdfunding: An exploratory study. Journal of Business Venturing, Vol. 29, No. 1, 1-16.

Moritz, A., Block, J. and Lutz, E. (2015), Investor communication in equity-based crowdfunding: a qualitative-empirical study. Qualitative Research in Financial Markets, Vol. 7, No. 3, 309-342.

Myers, S. C. (1977), Determinants of corporate borrowing. Journal of Financial Economics, Vol. 5, No, 2, 147-175.

Myers, S. C. and Majluf, N. S. (1984), Corporate financing and investment decisions when firms have information that investors do not have. Journal of Financial Economics, Vol. 13, No. 2, 187-221.

OECD, (2011), Financing High-Growth Firms: The Role of Angel Investors. OECD Publishing. Available at: http://dx.doi.org/10.1787/9789264118782-en.

OECD, (2017), Business and Finance Outlook. OECD Publishing. Available at http://www.oecd.org.

Oranburg, S. C. (2015), Bridgefunding: Crowdfunding and the Market for Entrepreneurial Finance. Cornell Journal of Law and Public Policy, Vol. 25, No. 2, $397-452$.

Paul, S., and Whittam, G. (2010), Business angel syndicates: An exploratory study of gatekeepers. Venture Capital: An International Journal of Entrepreneurial 
Finance, Vol. 12, No. 3, 241-256.

Petersen, R. and Carpenter, B. (2002), Is The Growth of Small Firms Constrained By Internal Finance? Review of Economics and Statistics, Vol. 84, No. 2, 298-309.

Petersen, M. A. and Rajan, R. G. (1997), Trade credit: theories and evidence. Review of Financial Studies, Vol. 10, no. 3, 661-691.

Pichler, F. and Tezza, I. (2016), Crowdfunding as a new Phenomenon: Origins, Features and Literature Review. In In Bottiglia, R. and Pichler, F. (eds.), Crowdfunding for SMEs: A European Perspective, London, UK: Palgrave Macmillan, 5-43.

Politis, D. (2008). Business angels and value added: What do we know and where do we go? Venture Capital: An International Journal of Entrepreneurial Finance, Vol. 10, No. 2, 127-147.

Pope, N. D. (2011), Crowdfunding Microstartups: It's Time for the Securities and Exchange Commission to Approve Small Offering. Journal of Business Law, Vol. 13, No. 4, 101-129.

Popper, N. (2017), Doubts Arise as Investors Flock to Crowdfunded Start-Ups. New York Times. Available at: https://www.nytimes.com/2017/01/24/ business/dealbook/crowdfunding-fraud-investing-startups.html.

Quittner, J. (2016), Why the Most Significant Part of the JOBS Act Has Yet to Catch On. Fortune, September 20, 2016. Available at: http://fortune.com/2016/09/19/fixing-the-jobs-act.

Robinson, D. T. and Sensoy, B. A. (2013), Do Private Equity Fund Managers Earn Their Fees? Compensation, Ownership, and Cash Flow Performance. Review of Financial Studies, Vol. 26, No. 11, 2760-2797.

Sahlman, W.A. (1990), The structure and governance of venture capital organizations. Journal of Financial Economics, Vol. 27, No. 2, 473-524.

Schwienbacher, A. (2009), Financing commitments and investors incentives in entrepreneurial firms. London School of Economics and Political Science, Working paper, No. 071/2009.

Sensoy, B. A., Wang, Y. and Weisbach, M. S. (2014), Limited partner performance and the maturing of the private equity industry. Journal of Financial Economics, Vol. 112, No. 3, 320-343.

Signori, A. and Vismara, S. (2016), Returns on Investments in Equity Crowdfunding. Available at SSRN: https://ssrn.com/abstract $=2765488$.

Smith, D. G. (2005), The Exit Structure of Venture Capital. UCLA Law Review, Vol. 53, No. 2, 315-356.

Sohl, J. E. (1999), The early-stage equity market in the USA. Venture Capital: An International Journal of Entrepreneurial Finance, Vol. 1, No. 2, 101-120. 
Sohl, J. E. (2007), The organisation of the informal venture capital market. In Landström, H. (ed.), Handbook of Research on Venture Capital. Cheltenham, UK: Edward Elgar Publishing, 347-368.

Sohl, Jeffrey, (2012), The changing nature of the angel market. In Landström, H. and Mason, C. (eds.). Handbook of Research on Venture Capital. Volume 2, Cheltenham, UK: Edward Elgar Publishing, chapter 2, 17-41.

Statista, (2018), Statista dossier on crowdfunding. Available at: https://www.statista.com/study/13089/crowdfunding-statista-dossier.

Sudek, R., Mitteness, C., and Baucus, M. (2008), Betting on the horse or the jockey: The impact of expertise on angel investing. Venture Capital: An International Journal of Entrepreneurial Finance, Vol. 14, No. 4, 241-267.

Tian, X. (2011), The Causes and Consequences of Venture Capital Stage Financing, Journal of Financial Economics, Vol. 101, No. 1, 132-159.

Triago (2018), The Triago Quarterly, July 2018

Triantis, G. G. (2001), Financial Contract Design in the World of Venture Capital, University of Chicago Law Review, Vol., 68, No. 1, 305-312.

Valanciene, L., and Jegeleviciute, S. (2013), Valuation of crowdfunding: Benefits and drawbacks. Economics and Management, Vol. 18, No. 1, 9-48.

Van Osnabrugge, M. (2000), A comparison of business angel and venture capitalist investment procedures: An agency theory-based analysis. Venture Capital: An International Journal of Entrepreneurial Finance, Vol. 2, No. 2, 91-109.

Vismara, S. (2018), Signaling to overcome inefficiencies in crowdfunding markets. In Cumming, D. and Hornuf, L. (eds.), The Economics of Crowdfunding, London, UK: Palgrave Macmillan, 29-56.

Wallmeroth, J., Wirtz, P. and Groh, A. P. (2018), Venture Capital, Angel Financing, and Crowdfunding of Entrepreneurial Ventures: A Literature Review. Foundations and Trends ${ }^{\circledR}$ in Entrepreneurship, Vol. 14, No. 1, 1-129.

Wang, H. J., and Zhang, R. (2012), Private Equity Investment and Management Team Incentive Alignment. Management World, Vol. 9, No. 4, 156-167.

Wang, T. (2013), Corporate Securities Fraud: Insights from a New Empirical Framework. Journal of Law, Economics and Organization, Vol. 29, No. 6, 535-568.

Weinstein, R. S. (2013), Crowdfunding in the U.S. and Abroad: What to Expect When You're Expecting. Cornell International Law Journal Vol. 46, No. 2, 427-453.

Wilson, K. E., (2015), Policy Lessons from Financing Young Innovative Firms. OECD, Science, Technology and Innovation Directorate Policy Paper, No. 24, 1-39.

Wilson, K. E., Duruflè, G. and Hellmann, T. (2018), From Start-Up to Scale-Up. Examining Public Policies for the Financing of High-Growth Ventures. In Mayer, C., Micossi, S., Onado, M., Pagano, M. and Polo, A. (eds.), Finance and 
Investment: The European Case, Oxford, UK: Oxford University Press, 179-220.

Wiltbank, R. and Boeker, W. (2007), Returns to angel investors in groups. November 2007. Available at: http://ssrn.com/paper $=1028592$.

Wiltbank, R., Read, S., Dew, N. and Sarasvathy, S. D. (2009), Prediction and control under uncertainty: Outcomes in angel investing. Journal of Business Venturing. Vol. 24, No. 2, 116-133.

Winborg, J. and Landström, H. (2001), Financial Bootstrapping in small Businesses; Examining Small Business Managers' Resource Acquisition Behaviors. Journal of Business Venturing, Vol. 16, No. 3, 235-254.

Wong, A., Bhatia, M., and Freeman, Z. (2009), Angel finance: The other venture capital. Strategic Change, Vol. 18, No. 7-8, 221-230.

Wright, M. and Robbie, K. (1998), Venture Capital and Private Equity: A Review and Synthesis. Journal of Business Finance and Accounting, Vol. 25, No. 5-6, 521-570.

Zhang, Z., Wardrop, R., Rau, P.R. and Gray, M. (2015), Moving Mainstream The European Alternative Finance Benchmarking Report. University of Cambridge and EY, February 2015, London, 1-44. 